\title{
Hydrogeologic Framework of Bedrock Units and Initial Salinity Distribution for a Simulation of Groundwater Flow for the Lake Michigan Basin
}



Scientific Investigations Report 2009-5060 
Cover image: Three-dimensional rendering of surficial topography and hydrogeologic layers beneath the Lake Michigan Basin. (Image by David Lampe, U.S. Geological Survey.) 


\section{Hydrogeologic Framework of Bedrock Units and Initial Salinity Distribution for a Simulation of Groundwater Flow for the Lake Michigan Basin}

By David C. Lampe

National Water Availability and Use Pilot Program

Scientific Investigations Report 2009-5060 


\title{
U.S. Department of the Interior \\ KEN SALAZAR, Secretary
}

\author{
U.S. Geological Survey \\ Suzette M. Kimball, Acting Director
}

U.S. Geological Survey, Reston, Virginia: 2009

For more information on the USGS - the Federal source for science about the Earth, its natural and living resources, natural hazards, and the environment, visit http://www.usgs.gov or call 1-888-ASK-USGS

For an overview of USGS information products, including maps, imagery, and publications, visit http://www.usgs.gov/pubprod

To order this and other USGS information products, visit http://store.usgs.gov

Any use of trade, product, or firm names is for descriptive purposes only and does not imply endorsement by the U.S. Government.

Although this report is in the public domain, permission must be secured from the individual copyright owners to reproduce any copyrighted materials contained within this report.

Suggested citation:

Lampe, D.C., 2009, Hydrogeologic framework of bedrock units and initial salinity distribution for a simulation of groundwater flow for the Lake Michigan Basin: U.S. Geological Survey Scientific Investigations Report 2009-5060, 49 p. 


\section{Contents}

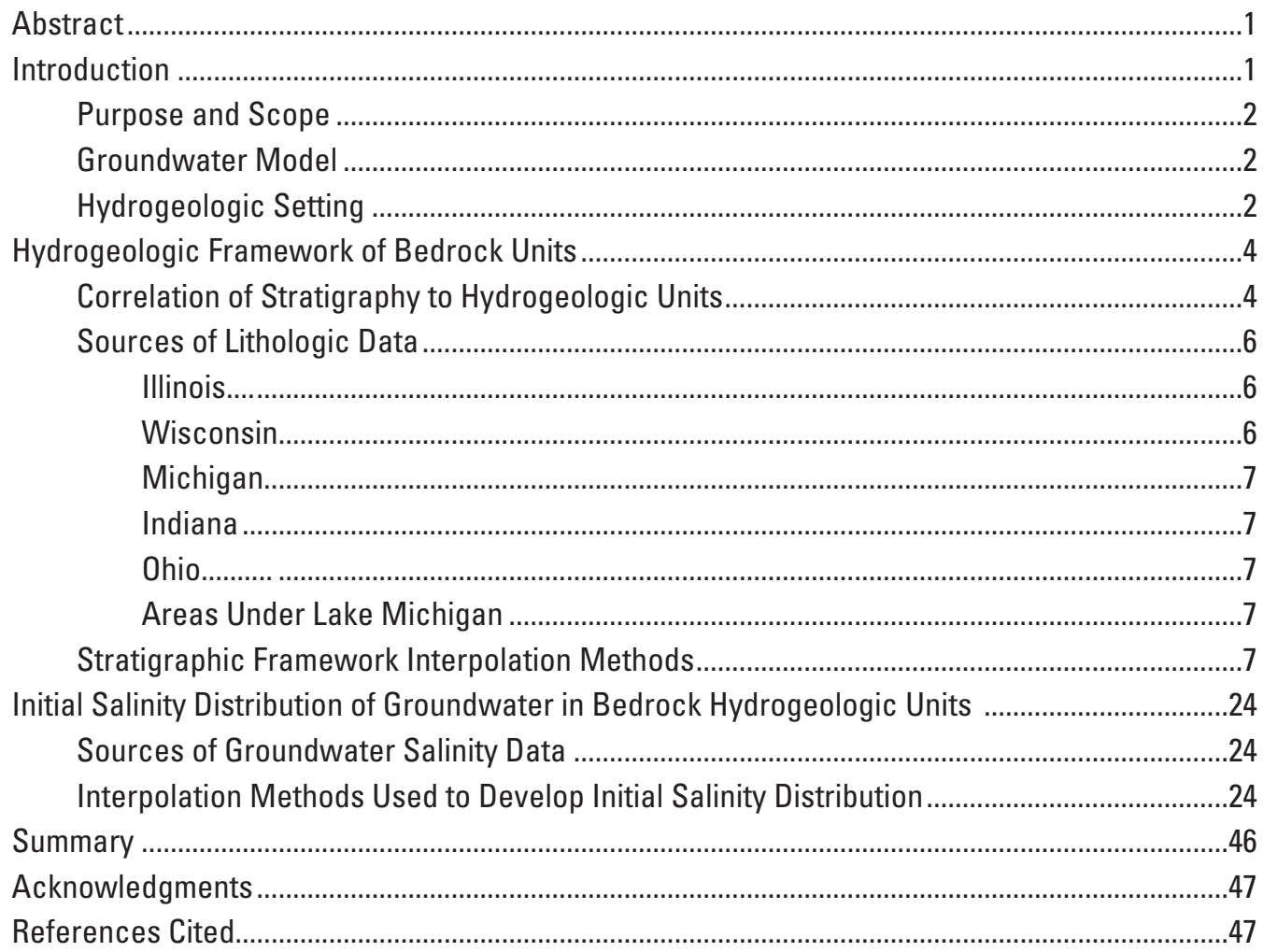

\section{Figures}

1. Map showing the location of Lake Michigan Basin, groundwater-model boundary and innermost model domain, structural geologic features, and general bedrock geology of the study area.

2. Stratigraphic chart showing time- and rock-stratigraphic framework nomenclature for the Lake Michigan Basin region, the U.S. Geological Survey principal aquifers in the model area, and the hydrogeologic units used in the model.

3-17. Maps showing thickness of-

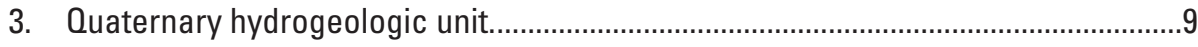

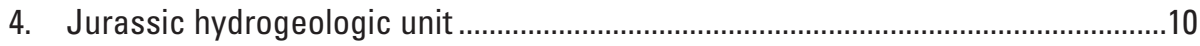

5. Upper Pennsylvanian hydrogeologic unit...........................................................11

6. Lower Pennsylvanian hydrogeologic unit ............................................................12

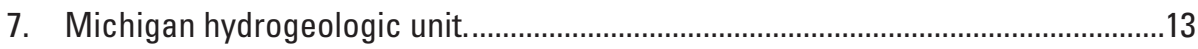

8. Marshall hydrogeologic unit...........................................................................14

9. Devonian-Mississippian hydrogeologic unit......................................................15



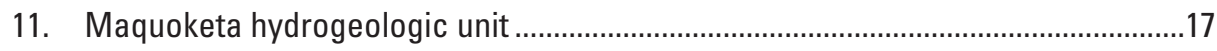

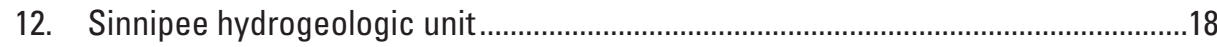

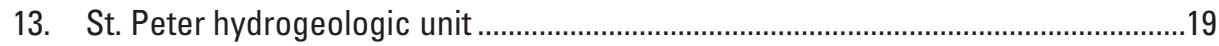

14. Prairie du Chien-Franconia hydrogeologic unit ..................................................20 


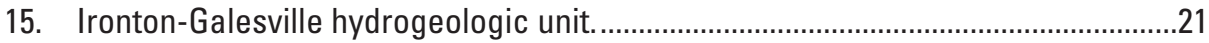

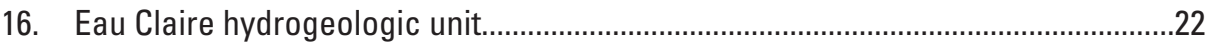

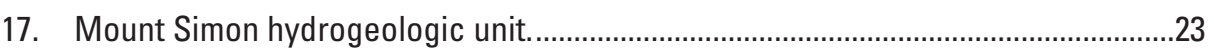

18. Graph showing groundwater density and total dissolved-solids concentrations for data from Gupta (1993).

19-38. Maps showing the initial total dissolved-solids concentration of groundwater in-

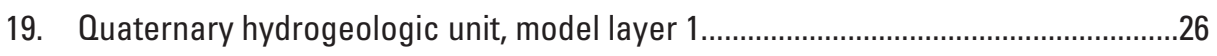

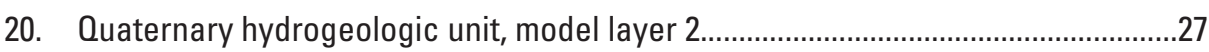

21. Quaternary hydrogeologic unit, model layer 3...................................................28

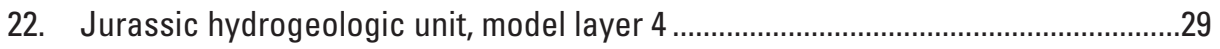

23. Upper Pennsylvanian hydrogeologic unit, model layer 5 ........................................30

24. Lower Pennsylvanian hydrogeologic unit, model layer 6 ..........................................31

25. Michigan hydrogeologic unit, model layer 7 ………............................................32

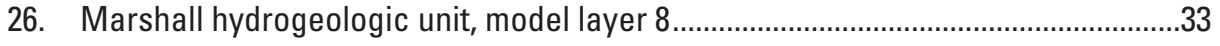

27. Devonian-Mississippian hydrogeologic unit, model layer 9 .....................................34



29. Silurian-Devonian hydrogeologic unit, model layer 11 ..........................................36

30. Silurian-Devonian hydrogeologic unit, model layer 12 ..........................................37

31. Maquoketa hydrogeologic unit, model layer 13 ................................................38

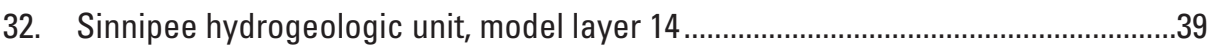

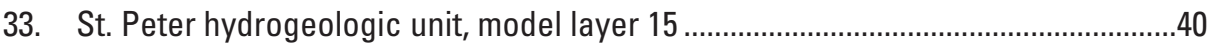

34. Prairie du Chien-Franconia hydrogeologic unit, model layer 16 ...........................41

35. Ironton-Galesville hydrogeologic unit, model layer 17...........................................42

36. Eau Claire hydrogeologic unit, model layer 18....................................................43

37. Mount Simon hydrogeologic unit, model layer 19...................................................4

38. Mount Simon hydrogeologic unit, model layer 20...................................................45

\section{Tables}

1. Sources of lithologic data for each State in the study area.............................................

2. Maximum thicknesses for each hydrogeologic unit........................................................



4. Hydrogeologic units, model layers, data sources, and maximum total dissolvedsolids concentration for the initial salinity concentrations 


\section{Conversion Factors}

\begin{tabular}{lcl}
\hline \multicolumn{1}{c}{ Multiply } & By & \multicolumn{1}{c}{ To obtain } \\
\hline & Length & \\
\hline foot $(\mathrm{ft})$ & 0.3048 & meter $(\mathrm{m})$ \\
mile $(\mathrm{mi})$ & 1.609 & kilometer $(\mathrm{km})$ \\
\hline & Area & \\
\hline square mile $\left(\mathrm{mi}^{2}\right)$ & 259.0 & hectare (ha) \\
square mile $\left(\mathrm{mi}^{2}\right)$ & 2.590 & square kilometer $\left(\mathrm{km}^{2}\right)$ \\
\hline & Volume & \\
\hline liter (L) & 33.82 & ounce, fluid (fl. oz) \\
liter (L) & 2.11 & pint $(\mathrm{pt})$ \\
liter (L) & 1.0566 & quart (qt) \\
liter (L) & 0.264 & gallon (gal) \\
\hline & Density & \\
\hline pound per cubic foot $\left(\mathrm{lb} / \mathrm{ft}^{3}\right)$ & 16.02 & kilogram per cubic meter $\left(\mathrm{kg} / \mathrm{m}^{3}\right)$ \\
\hline
\end{tabular}

Vertical coordinate information is referenced to the North American Vertical Datum of 1988 (NAVD 88).

Horizontal coordinate information is referenced to the North American Datum of 1983 (NAD 83).

Altitude, as used in this report, refers to distance below the vertical datum.

Concentrations of chemical constituents in water are given in milligrams per liter (mg/L).

\section{Abbreviations}

$\begin{array}{ll}\text { ASCII } & \text { American Standard Code for Information Interchange } \\ \text { DEM } & \text { Digital Elevation Model } \\ \text { GIS } & \text { Geographic Information System } \\ \text { GWRP } & \text { Groundwater Resources Program } \\ \text { IGS } & \text { Indiana Geological Survey } \\ \text { USGS } & \text { U.S. Geological Survey } \\ \text { WCR } & \text { Well construction report }\end{array}$




\title{
Hydrogeologic Framework of Bedrock Units and Initial Salinity Distribution for a Simulation of Groundwater Flow for the Lake Michigan Basin
}

\author{
By David C. Lampe
}

\begin{abstract}
The U.S. Geological Survey is assessing groundwater availability in the Lake Michigan Basin. As part of the assessment, a variable-density groundwater-flow model is being developed to simulate the effects of groundwater use on water availability throughout the basin. The hydrogeologic framework for the Lake Michigan Basin model was developed by grouping the bedrock geology of the study area into hydrogeologic units on the basis of the functioning of each unit as an aquifer or confining layer within the basin. Available data were evaluated based on the areal extent of coverage within the study area, and procedures were established to characterize areas with sparse data coverage. Top and bottom altitudes for each hydrogeologic unit were interpolated in a geographic information system for input to the model and compared with existing maps of subsurface formations. Fourteen bedrock hydrogeologic units, making up 17 bedrock model layers, were defined, and they range in age from the Jurassic Period red beds of central Michigan to the Cambrian Period Mount Simon Sandstone.

Information on groundwater salinity in the Lake Michigan Basin was compiled to create an input dataset for the variable-density groundwater-flow simulation. Data presented in this report are referred to as "salinity data" and are reported in terms of total dissolved solids. Salinity data were not available for each hydrogeologic unit. Available datasets were assigned to a hydrogeologic unit, entered into a spatial database, and data quality was visually evaluated. A geographic information system was used to interpolate salinity distributions for each hydrogeologic unit with available data. Hydrogeologic units with no available data either were set equal to neighboring units or were vertically interpolated by use of values from units above and below.
\end{abstract}

\section{Introduction}

At the request of Congress, the U.S. Geological Survey (USGS) Groundwater Resources Program (GWRP) was established to identify, measure, and assess the Nation's groundwater resources. A pilot phase of the GWRP is the water availability and use initiative that focuses on the Great Lakes region (U.S. Geological Survey, 2002). The goal of the initiative is to provide information about trends in water availability and use and to develop an improved capability to forecast the availability of water for future economic and ecological uses. The best methods of evaluating the resource must be determined and used with the resulting information delivered in a manner that helps citizens, communities, and natura1-resource managers gain an improved understanding of the Nation's water resource.

To aid in forecasting water availability, a variable-density groundwater-flow model is being developed for the Lake Michigan Basin and surrounding area. The Lake Michigan Basin was selected for the study for the following reasons:

1. The entire watershed is in the United States, and many datasets already are available within the USGS.

2. Groundwater is withdrawn from bedrock and glacialdeposit aquifers, both of which are important aquifer systems throughout the Great Lakes Basin.

3. Important issues related to groundwater and surface-water interaction can be simulated with the model.

4. Groundwater withdrawals in the Lake Michigan Basin may affect the locations of groundwater divides with Lakes Superior, Huron, and Erie.

5. Problems caused by large-scale groundwater withdrawals have been documented in the basin (Grannemann and Reeves, 2005). 
Development of the model is a focused effort to simulate flow of groundwater at a regional scale and is a component in understanding the water balance in the basin. The model should identify the source of water to wells, define the complexities of the drainage basin, and provide a regional framework for use in future, smaller scale groundwater-flow simulations.

A groundwater-flow model requires multiple datasets that define hydrogeologic conditions in the area of study. A fundamental dataset for any groundwater-flow model is information on the description and distribution of geologic materials that underlie the area to be modeled. Mapping of the distribution of important aquifers and confining units is needed to define the hydrogeologic framework for a model.

Although the Lake Michigan Basin is the focus of the GWRP modeling effort, the model extends into neighboring drainage basins, including the Mississippi River Basin and other Great Lakes basins. Because of the large size and complexity of the study area, an extensive literature review was completed and multiple datasets were compiled to characterize the bedrock geology of the study area. Data for hydrogeologic units were compiled separately for overlying unconsolidated sediments (Arihood, 2008) and for bedrock units.

In most cases, groundwater-flow models are used to estimate the flow of freshwater in aquifers. However, in many geologic structural basins, aquifers may be saturated with naturally occurring brines that can affect the movement of fluids through geologic formations. Groundwater in many bedrock formations within the Lake Michigan Basin is affected by highly saline brines from sources within the Michigan Structural Basin. The interaction of brines with surrounding freshwater cannot be simulated by the standard USGS MODFLOW-2000 code that is commonly used for regional groundwater-flow models (Harbaugh and others, 2000). A second code, SEAWAT-2000, was developed to include the effects of variable density on groundwater flow (Langevin and others, 2003).

The use of the variable density SEAWAT-2000 code in place of MODFLOW-2000 requires additional information, including the distribution of salinity throughout the model domain. Salinity is considered either as an initial condition subject to evolution through time or, as in the case of the Lake Michigan Basin model, as a fixed condition influencing the circulation of groundwater. A literature review was performed and datasets were compiled to evaluate the distribution of salinity in groundwater in the study area.

\section{Purpose and Scope}

This report describes the sources of data and the methods used to develop the hydrogeologic framework of bedrock units and the sources of data and the methods used to map the salinity of groundwater in the Lake Michigan Basin and surrounding area. The maps of the hydrogeologic framework and the salinity data are intended for use as input data for simulation of groundwater flow in the Lake Michigan Basin. Bedrock lithologic data from approximately 54,000 well records were compiled, evaluated for discrepancies, and interpolated in a geographic information system (GIS) to develop maps for each hydrogeologic unit simulated in the model. These data were supplemented by data and maps from previous investigations. Salinity data evaluated for this report included total dissolved solids concentrations and density determinations. A linear relation between salinity and density was developed to infer concentrations where only density data were available. Methods to extend interpretations into areas having little or no data are described. Results are presented in maps showing thickness and concentration of total dissolved solids for each hydrogeologic unit and corresponding model layer.

\section{Groundwater Model}

The area of study for the Lake Michigan Basin groundwater model is approximately $180,000 \mathrm{mi}^{2}$ and incorporates the entire drainage basin of the lake (approximately 45,000 $\mathrm{mi}^{2}$ ) and adjacent parts of Michigan; Indiana; Illinois; Ohio; Wisconsin; and Ontario, Canada (fig. 1). The model simulates flow of groundwater in unconsolidated sediments and sedimentary rocks extending below the surface to the crystalline rocks of Precambrian age.

Groundwater-flow models use the mathematical method of finite difference to compute approximate solutions to differential equations that describe the flow of groundwater in space and time. Models require three-dimensional discretization of the area to be modeled, resulting in a grid network in the horizontal dimension and layers in the vertical dimension. The intersections of the grid with the layers form model cells that are assigned dimensions and hydraulic properties.

The Lake Michigan Basin groundwater model is discretized into a grid of 391 by 261 cells. The model has 20 layers: 3 that simulate the glacial and unconsolidated sediments and 17 that simulate the bedrock units. The model provides additional detail in the area of greatest interest, in this case, the Lake Michigan Basin, by use of smaller grid spacing in the innermost model domain (fig. 1) compared with the grid spacing at the model boundaries. The smallest interior grid cells are 5,000 by $5,000 \mathrm{ft}$. At the model boundaries, the size of grid cells reaches approximately $68,930 \mathrm{ft}(13 \mathrm{mi})$ from north to south by $116,490 \mathrm{ft}$ (22 mi) from east to west.

\section{Hydrogeologic Setting}

The study area for the Lake Michigan Basin groundwater-flow model encompasses the entire Michigan Structural Basin centered in the Lower Peninsula of Michigan and extending into parts of Illinois, Wisconsin, Indiana, Ohio, and Ontario, Canada. The Michigan Structural Basin is bounded by the Canadian Shield to the north, the Wisconsin Arch to the west, the Kankakee Arch to the southwest, the Findlay Arch to the southeast, and the Algonquin Arch to the east (Olcott, 1992, fig. 9; Lloyd and Lyke, 1995, fig. 6) (fig. 1). 


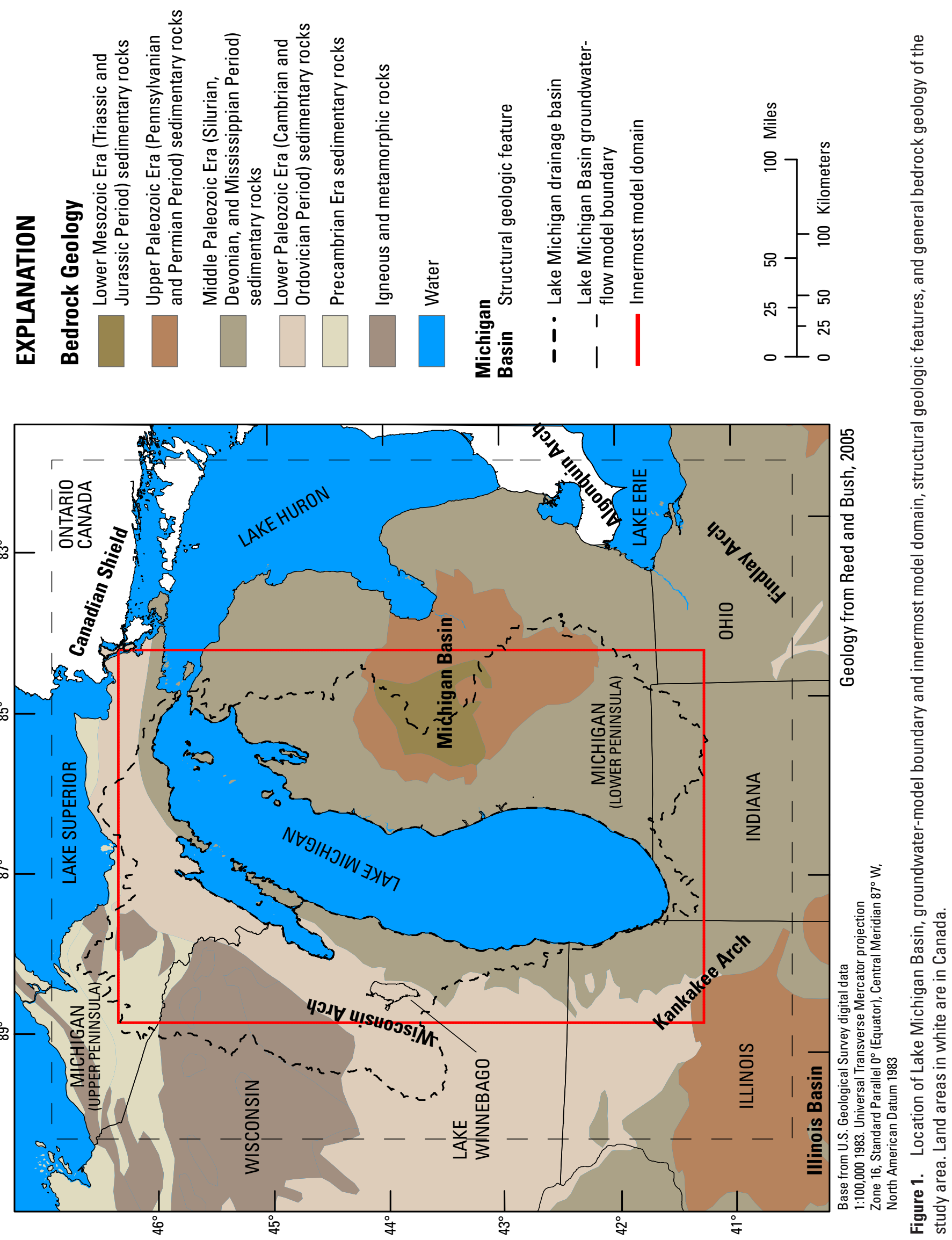


The Kankakee Arch separates the Michigan Structural Basin from the Illinois Structural Basin - part of which is included in the southwest section of the study area. The Findlay Arch separates the Michigan Structural Basin from the Appalachian Structural Basin to the southeast (Colton, 1962). Cambrian rocks of the Wisconsin Arch make up the western boundary of the model.

Within the Michigan Structural Basin, Precambrian crystalline rocks and the Precambrian Jacobsville Sandstone are overlain by approximately $14,000 \mathrm{ft}$ of younger Paleozoic and Mesozoic Era sedimentary rocks (Cohee and others, 1951; fig. 2). The Paleozoic Era rocks are made up of Cambrian Period sandstones and dolomites, Ordovician Period sandstones and limestones overlain by shale, Silurian and Devonian Period limestones and dolomites, and Mississippian Period limestones and shales. The Mesozoic Era rocks are made up of Pennsylvanian Period sandstones and shales and Jurassic Period sandstones. These rocks are overlain by glacial deposits from Wisconsinan age and earlier glaciations and unconsolidated sediment of recent age. All of the glacial and unconsolidated sediments and sedimentary rocks located within the boundary of the study area are included within the Lake Michigan Basin model.

\section{Hydrogeologic Framework of Bedrock Units}

The sedimentary rocks within the boundary of the simulation were divided into 14 hydrogeologic units. The 14 units were then subdivided into a total of 17 model layers for use within the simulation (fig. 2). The Silurian-Devonian and Mount Simon hydrogeologic units were subdivided into three and two model layers, respectively. Both the hydrogeologic units and model layers were identified by evaluating the major lithology of the geologic formation and its relative importance as a water-bearing formation within the simulation area.

\section{Correlation of Stratigraphy to Hydrogeologic Units}

Six aquifers designated by the USGS as "principal aquifers" are within the model area (fig. 2; Olcott, 1992). The surficial aquifer system is found within the Quaternary hydrogeologic model unit. The Pennsylvanian aquifer is simulated by the upper Pennsylvanian hydrogeologic unit. The Mississippian aquifer is simulated by the Marshall hydrogeologic unit and partially by the Michigan and Devonian-Mississippian hydrogeologic units. The Silurian-Devonian aquifer is simulated by the Silurian-Devonian and parts of the Maquoketa hydrogeologic units. The Cambrian-Ordovician aquifer is simulated by the Maquoketa, Sinnipee, St. Peter, Prairie du Chien-Franconia, Ironton-Galesville, Eau Claire and Mount Simon hydrogeologic units. The Jacobsville aquifer is simulated by parts of the Mount Simon hydrogeologic unit.
Figure 2 shows the correlation of units in the model. Confining units are shown in red, aquifers in blue, and units that act as aquifers in some parts of the model area and confining units in others are shown in light blue. Five of the 15 hydrogeologic units simulate aquifer materials, 4 of the 15 units simulate confining unit materials, and 6 of the 15 units describe units that have properties of aquifers and confining units. The basal confining unit of the Lake Michigan Basin groundwater flow model is the Precambrian crystalline rock that underlies the entire model area. Overlying the crystalline rock is the Precambrian Jacobsville Sandstone, which is located in the Upper Peninsula of Michigan, and a series of Cambrian and Ordovician aquifers including the Mount Simon Formation, the Ironton and Galesville Sandstones, and the St. Peter Sandstone. An upper Ordovician confining unit, the Maquoketa Group, primarily consisting of shale, underlies a series of Silurian and Devonian limestones and dolomites. The Silurian-Devonian hydrogeologic unit was divided into three model layers. The uppermost of the three model layers represents a discontinuous eroded surface in parts of the model area. The remaining portion of the unit was divided into two model layers based upon thickness. Mississippian and Devonian shales form a confining unit above the Silurian and Devonian limestones and dolomites and are overlain by Quaternary glacial deposits in Illinois, Indiana, Ohio and parts of Wisconsin.

Bedrock units that are younger than the DevonianMississippian confining unit are not present within the model area outside the state of Michigan (fig. 2). Within Michigan, the Marshall Sandstone is overlain by the Michigan Formation confining unit. The Bayport Limestone, Parma Sandstone, and the shale portion of the Saginaw Formation make up the Lower Pennsylvanian hydrogeologic unit. The remainder of the Saginaw Formation and Grand River Formations make up the upper Pennsylvanian hydrogeologic unit and are partially overlain by the Jurassic Ionia Formation. Quaternary glacial deposits completely cover the bedrock within the modeled area, except for parts of the bedrock in the Upper Peninsula of Michigan.

Some hydrogeologic units in the Lake Michigan Basin groundwater-flow model act as aquifers in some parts of the model area and confining units in other areas of the model (fig. 2). The Eau Claire hydrogeologic unit acts as an aquifer where it is a coarse grained sandstone in Michigan's Upper Peninsula and northeastern Wisconsin, but it acts as a confining unit where it becomes finer grained in southeastern Wisconsin. In northeastern Illinois, the Eau Claire hydrogeologic unit is a siltstone and acts as a confining unit. The Prairie du Chien-Franconia hydrogeologic unit can be an aquifer where karstic dolomite is present or where the sandstone units dominate; but, often, where no karst is present and the clastic sedimentary rocks are siltstones, this unit can act as a confining unit. The Sinnipee hydrogeologic unit, when overlain by the Maquoketa hydrogeologic unit, is unweathered and acts as a confining unit. Weathered portions of the unit are aquifers. 


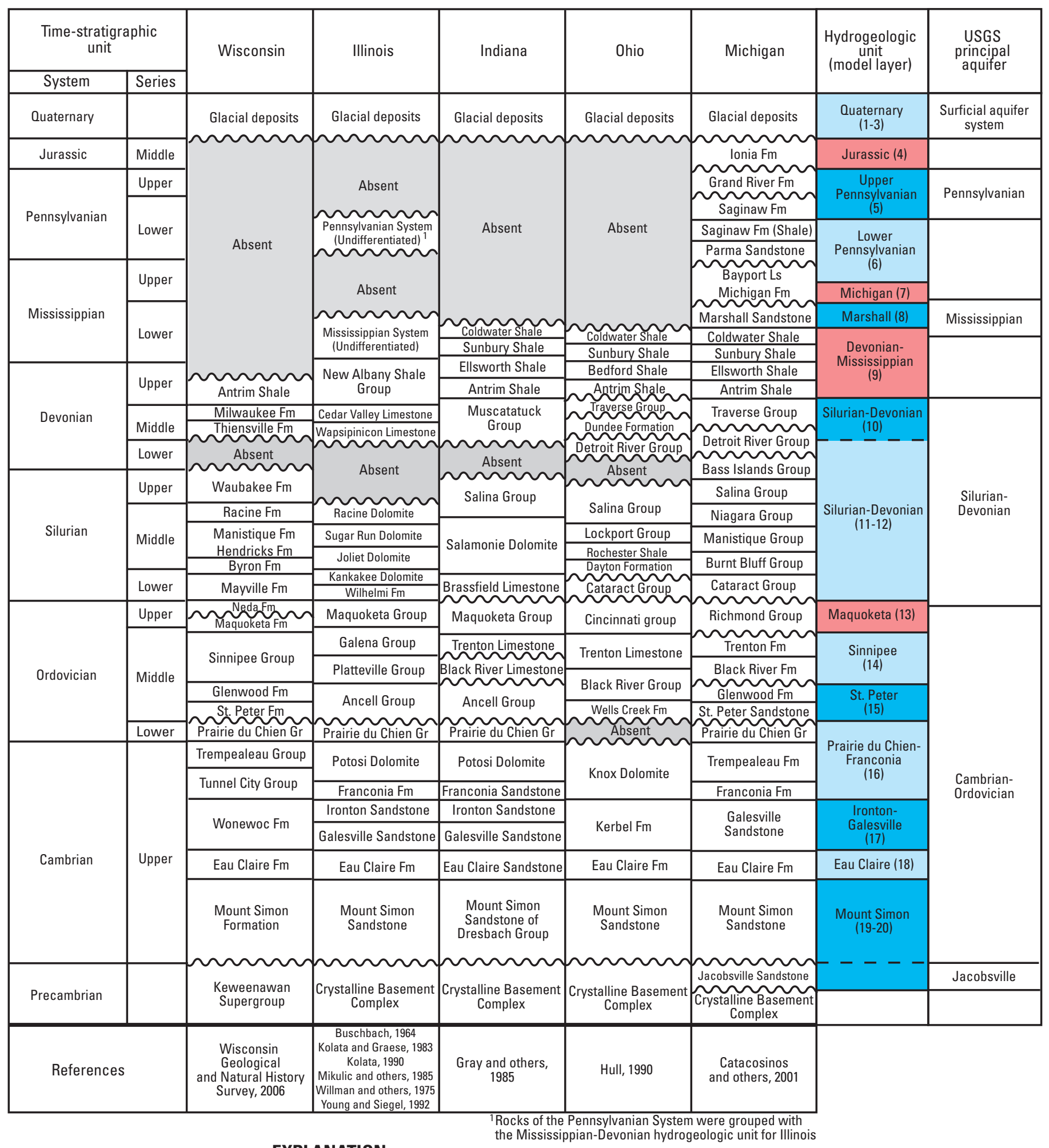

\section{EXPLANATION}

$\begin{array}{lll}\text { Aquifer } & \text { Depositional surface } & \text { Gr, Group } \\ \text { Aquifer/confining unit } & \text { Erosional surface } & \text { Fm, Formation } \\ \text { Confining unit } & & \text { Ls, Limestone }\end{array}$

Figure 2. Stratigraphic chart showing time- and rock-stratigraphic framework nomenclature for the Lake Michigan Basin region, the U.S. Geological Survey principal aquifers in the model area, and the hydrogeologic units used in the model. 
Model layers 11 and 12 of the Silurian-Devonian hydrogeologic unit are aquifers in Wisconsin and Illinois, but the layers act as a confining unit in Michigan due to changes in lithology. The Lower Pennsylvanian hydrogeologic unit is dominated by the Parma Sandstone and Bayport Limestone, which act as aquifers in south central Michigan. In other areas, the unit is made up of shale of the Saginaw Formation, thus making it a confining unit.

\section{Sources of Lithologic Data}

Several studies have gathered data on bedrock stratigraphy for parts of the Lake Michigan Basin model study area. Prior to 2006, few data sources describe the bedrock geology beneath Lake Michigan. Kontis and Mandle (1980) developed a computerized database system to facilitate the collection, evaluation, and manipulation of large quantities of hydrogeologic information used during the development of the stratigraphic framework of the northern Midwest Regional AquiferSystem Analysis for parts of Illinois, Wisconsin, Michigan and Indiana. Feinstein and others (2005) described the geologic framework for a regional model for southeastern Wisconsin. Bricker and others (1983) compiled sources of CambrianOrdovician bedrock formations and developed maps showing the structure and thickness of the formations for the state of Michigan. S.C. Meyer and others (Illinois State Water Survey, written commun., 2008) described the geologic framework for a regional model of northeastern Illinois.

Lithologic data from well records and from prior investigations were compiled to map the distribution of hydrogeologic units within the Lake Michigan Basin model study area. The sources of this information are listed for each State in table 1 .

\section{Illinois}

A recent study centered on northeastern Illinois (S.C. Meyer and others, Illinois State Water Survey, written commun., 2008) established a detailed hydrostratigraphic framework that included part of the Lake Michigan Basin groundwater-flow model that is in Illinois. This framework is similar in conception to the hydrostratigraphic layering developed in previous studies (Feinstein and others, 2005) for adjacent areas of Wisconsin.

\section{Wisconsin}

Lithologic information for parts of the study area in Wisconsin was retrieved from 6,813 well drillers' logs from the wiscLITH lithologic and stratigraphic database (Wisconsin Geologic and Natural History Survey, 2004). Well construction reports (WCR) were used to supplement the wiscLITH data (Wisconsin Department of Natural Resources, 2006). Information about depth to the top of the bedrock surface was provided from 15,179 WCRs and 6,625 WCRs provided additional information on the depth to crystalline Precambrian bedrock within the state.

Other datasets that describe specific areas of Wisconsin were used to supplement the wiscLITH database and WCRs. The southeastern portion of the state was described by the hydrologic framework developed for a groundwater model in southeast Wisconsin (Feinstein and others, 2005; Eaton and others, 1999). The hydrologic framework for a groundwater-flow model of a part of south-central Wisconsin by Krohelski and others (2000) was also included. Additional information on the top of bedrock was taken from (1) a lithologic database of parts of northeastern Wisconsin (B.A. Brown, Wisconsin Geological and Natural History Survey, written commun., 2005), (2) figures describing the thickness of glacial deposits in a part of northcentral Wisconsin (Batten, 1987), and (3) maps describing the elevation of the bedrock surface and the depth to Precambrian crystalline rock in an area south of Lake Winnebago (Batten, 2004; W.G. Batten, Wisconsin Geological and Natural History Survey, written commun., 2006). Additional information on the depth to Precambrian crystalline rock was obtained from R.D. Cotter (U.S. Geological Survey, unpublished data, 1986), Olcott (1966) and W.G. Batten (Wisconsin Geological and Natural History Survey, unpublished data, 1979).

Table 1. Sources of lithologic data for each State in the study area.

\begin{tabular}{ll}
\hline \multicolumn{1}{c}{ State } & \multicolumn{1}{c}{ Sources } \\
\hline Illinois & S.C. Meyer and others, Illinois State Water Survey, written commun., 2008 \\
Wisconsin & Batten (1987, 2004), Eaton and others (1999), Feinstein and others (2005), Krohelski and others (2000), \\
& Olcott (1966), Wisconsin Department of Natural Resources (2006), Wisconsin Geological and Natural \\
& History Survey (2004) \\
Michigan & Bricker and others (1983), Michigan Department of Environmental Quality (2008) \\
Indiana & Gray (2003), Indiana Geological Survey (2005) \\
Ohio & Ohio Division of Geological Survey (2005), Wickstrom and others (1992) \\
\hline
\end{tabular}




\section{Michigan}

Hydrogeologic unit surfaces within Michigan were interpreted primarily by use of 22,586 well logs from the Michigan Department of Environmental Quality's Wellogic database (Michigan Department of Environmental Quality, 2008).

Additional logs from wells in Quaternary deposits were also used to characterize the top of bedrock surface within Michigan (D.P. Lusch, Michigan State University, written commun., 2006). Isopach and structure maps from the Michigan Geological Survey also were used to define the St. Peter and lower hydrogeologic units where well log information was sparse (Bricker and others, 1983). Updated information from Nadon and others (2000) was used to characterize the extent of the St. Peter Sandstone in the Lower Peninsula of Michigan.

\section{Indiana}

Hydrogeologic unit surfaces within Indiana were interpreted by use of 2,753 oil and gas well logs from the Indiana Geological Survey's (IGS) Petroleum Database Management System, which contains oil and gas well logs for the state of Indiana (Indiana Geological Survey, 2005). Contours of the top of bedrock surface were used to characterize the bottom of the Quaternary hydrogeologic unit surface (Gray, 2003).

\section{Ohio}

Hydrogeologic unit surfaces within Ohio were interpreted by use of 749 well logs from Wickstrom and others (1992). Contours of the top of bedrock were used to characterize the bottom of the Quaternary hydrogeologic unit surface (Ohio Division of Geological Survey, 2005).

\section{Areas Under Lake Michigan}

Little information was found describing the bedrock units beneath Lake Michigan. The base altitude of the Antrim Shale was characterized by use of information from C.S. Swezey (U.S. Geological Survey, written commun., 2008).

\section{Stratigraphic Framework Interpolation Methods}

A hydrogeologic framework for a groundwater-flow model of northeastern Illinois, which includes the entire area of Illinois in the Lake Michigan Basin groundwater-flow model, was used as the sole data source for the state of Illinois (S.C. Meyer and others, Illinois State Water Survey, written commun., 2008). The hydrogeologic framework used for the northeastern Illinois groundwater-flow model corresponds to the framework used with the Lake Michigan Basin model, except for Pennsylvanian bedrock. The Illinois model grouped the Pennsylvanian Period bedrock with the Devonian-Mississippian Period bedrock because they have similar lithologies and physical properties. The Illinois Pennsylvanian bedrock units were therefore included with the Devonian-Mississippian hydrogeologic unit in the Lake Michigan Basin groundwaterflow model. The nodal data from the northeastern Illlinois groundwater-flow model were converted into ARC-INFO GIS point coverages (Environmental Systems Research Institute, 2003) for each hydrogeologic unit in Illinois.

The well log data for Wisconsin, Michigan, Indiana, and Ohio initially were assigned to multiple hydrogeologic units based on the lithologic log associated with each well. Landsurface altitude information reported for the well log was compared to the land-surface altitude interpreted from the digital elevation model (DEM) data for the study area. If the difference between the reported altitude of the well and the land surface DEM was greater than $10 \mathrm{ft}$, the reported altitude of the well $\log$ was investigated. If the source of the difference was not apparent, the well log was not used in the development of the hydrogeologic units. Each lithologic unit described in the well $\operatorname{logs}$ was assigned to a hydrogeologic unit (fig. 2). The lithologic log for a well included depth information for each lithologic unit. The depth information associated with the bottom of each hydrogeologic unit in the model was subtracted from the reported land-surface altitude of the well to obtain an altitude of the bottom of the unit. This process was repeated for each hydrogeologic unit described in the well log. Data points for each separate hydrogeologic unit in Michigan, Indiana and Ohio were grouped and then converted into an ARC-INFO point coverage (Environmental Systems Research Institute, 2003). Available contour data describing the elevation of the bedrock surface (bottom of hydrogeologic unit 1 , fig. 2) within the state of Indiana also were interpolated using the TOPOGRID command in ARC-INFO and then converted into ARC-INFO point coverages.

The hydrologic framework developed for a groundwater model in southeast Wisconsin (Feinstein and others, 2005; Eaton and others, 1999) has the same layering configuration as the Lake Michigan Basin groundwater-flow model. Nodal data from both the southeast Wisconsin model and a groundwaterflow model by Krohelski and others (2000) were converted into ARC-INFO point coverages (Environmental Systems Research Institute, 2003). All sources of data for Wisconsin were interpolated using the Surfer software package (Golden Software Inc., 2002). Contours of the interpolated Wisconsin data were visually inspected and evaluated for data inaccuracies within the Surfer software package. Files in ASCII format were then exported from the software and then converted into ARC-INFO point coverages.

Within Michigan, the Wellogic database included sparse information for the deeper hydrogeologic units in the Lower Peninsula. Isopach and structural contour maps (Bricker and others, 1983) were used to supplement the Wellogic data for the St. Peter through the Mount Simon hydrogeologic units (fig. 2). The contours were digitized and elevation surfaces were generated using the TOPOGRID command in ARCINFO, version 8.3 (Environmental Systems Research Institute, 2003). Structural contours of the top of the Glenwood 
Formation were used as the bottom of the Sinnipee hydrogeologic unit. Isopach data of the underlying formations were then subtracted from the bottom of the next youngest hydrogeologic unit, thus creating the surface altitude for the rest of the underlying units. These interpolated surfaces were then converted into ARC-INFO point coverages for each hydrogeologic unit.

The geologic logs for many of the wells used to define the hydrogeologic layering in the Michigan Structural Basin include the St. Peter Sandstone with underlying rock associated with the Prairie du Chien Formation. To separate the two hydrogeologic units, the bottom surface of the St. Peter was revised by use of contour information from a recent interpretation of its stratigraphy by Nadon and others (2000).

Point coverages for each hydrogeologic unit were grouped across states and then interpolated to create a topof-hydrogeologic-unit altitude surface using a kriging interpolator available in ARC-INFO, version 8.3 (Environmental Systems Research Institute, 2003). Within Michigan, interpolations were restricted to areas within the subcrop boundaries of each hydrogeologic unit, which were determined by use of the bedrock geology map of Michigan (Michigan Department of Environmental Quality, 1987). Because the USGS MODFLOW-2000 code requires continuous hydrogeologic units and model layers throughout the area of the model, areas outside of the subcrop boundaries were assigned an altitude equal to $0.2 \mathrm{ft}$ less than the overlying hydrogeologic unit to maintain the layer throughout the modeled area.

The interpolated surfaces were evaluated to determine if areas existed where surfaces crossed, indicating the absence of one or more hydrogeologic units. The lower, or older, surface was subtracted from the upper, or younger, surface to identify areas that had an apparent negative unit thickness. If the areas with apparent negative thickness were also mapped as areas where the unit is absent, the thickness of the hydrogeologic unit within that area was assigned an arbitrary value of $0.2 \mathrm{ft}$. If the areas with apparent negative thickness were not mapped as areas where the unit is absent, which was common in areas of sparse data coverage, artificial data points were used to control the results of the interpolation procedure. Points with values similar to existing well log data were included to produce a consistent surface across the area in question.

Because very few data were available for the geology beneath Lake Michigan, elevations for each hydrogeologic unit were linearly interpolated across the lake from data points in Wisconsin to points directly east in Michigan. This produced a decrease in elevation and a gradual thickening of the units from Wisconsin eastward into Michigan and the Michigan Structural Basin. The bottom of the Devonian-Mississippian hydrogeologic unit surface was adjusted to reduce the extent of the unit, thus making it similar to the unit extent interpreted by C.S. Swezey (U.S. Geological Survey, written commun., 2008) and J.A. East (U.S. Geological Survey, written commun., 2008) under Lake Michigan.
The interpolated surfaces were evaluated for accuracy within the Upper Peninsula of Michigan in areas with sparse data coverage (C.J. Hoard, U.S. Geological Survey, written commun., 2005). Additional data points were added to define thicknesses for the Prairie du Chien through Mount Simon hydrogeologic units in these areas.

Interpolated surfaces for each hydrogeologic unit were then converted to ASCII format text files that listed the elevations of each hydrogeologic unit in each cell of the groundwater-flow model. These altitude values for the hydrogeologic units were then imported into the Lake Michigan Basin groundwater-flow model.

Figures 3-17 display the unit thickness values for each hydrogeologic unit. The shaded elongated areas around the borders of the figures represent the larger cells at the boundary of the model. The uncharacteristic appearance of the Devonian-Mississippian hydrogeologic unit beneath Lake Michigan (fig. 9) is due to small amounts of Devonian-Mississippian materials found in eastern Wisconsin. Isolated blocks like those found near the Lake Michigan shore in Wisconsin (see figs. 10-14) represent areas where small amounts of data were present in a model cell outside of the innermost model domain. The maximum thicknesses for each hydrogeologic unit are listed in table 2. The Jurassic, Lower Pennsylvanian, Marshall and Ironton-Galesville hydrogeologic units have thicknesses less than $550 \mathrm{ft}$. The Silurian-Devonian hydrogeologic unit has thicknesses less than about 7,550 ft.

Table 2. Maximum thicknesses for each hydrogeologic unit.

\begin{tabular}{lr}
\hline Hydrogeologic unit & $\begin{array}{c}\text { Maximum thickness } \\
\text { (feet) }\end{array}$ \\
\hline Quaternary & 1,107 \\
Jurassic & 195 \\
Upper Pennsylvanian & 601 \\
Lower Pennsylvanian & 527 \\
Michigan & 720 \\
Marshall & 493 \\
Devonian-Mississippian & 2,260 \\
Silurian-Devonian & 7,538 \\
Maquoketa & 2,162 \\
Sinnipee & 1,632 \\
St. Peter & 1,364 \\
Prairie du Chien-Franconia & 2,060 \\
Ironton-Galesville & 543 \\
Eau Claire & 1,566 \\
Mount Simon & 3,014 \\
\hline
\end{tabular}



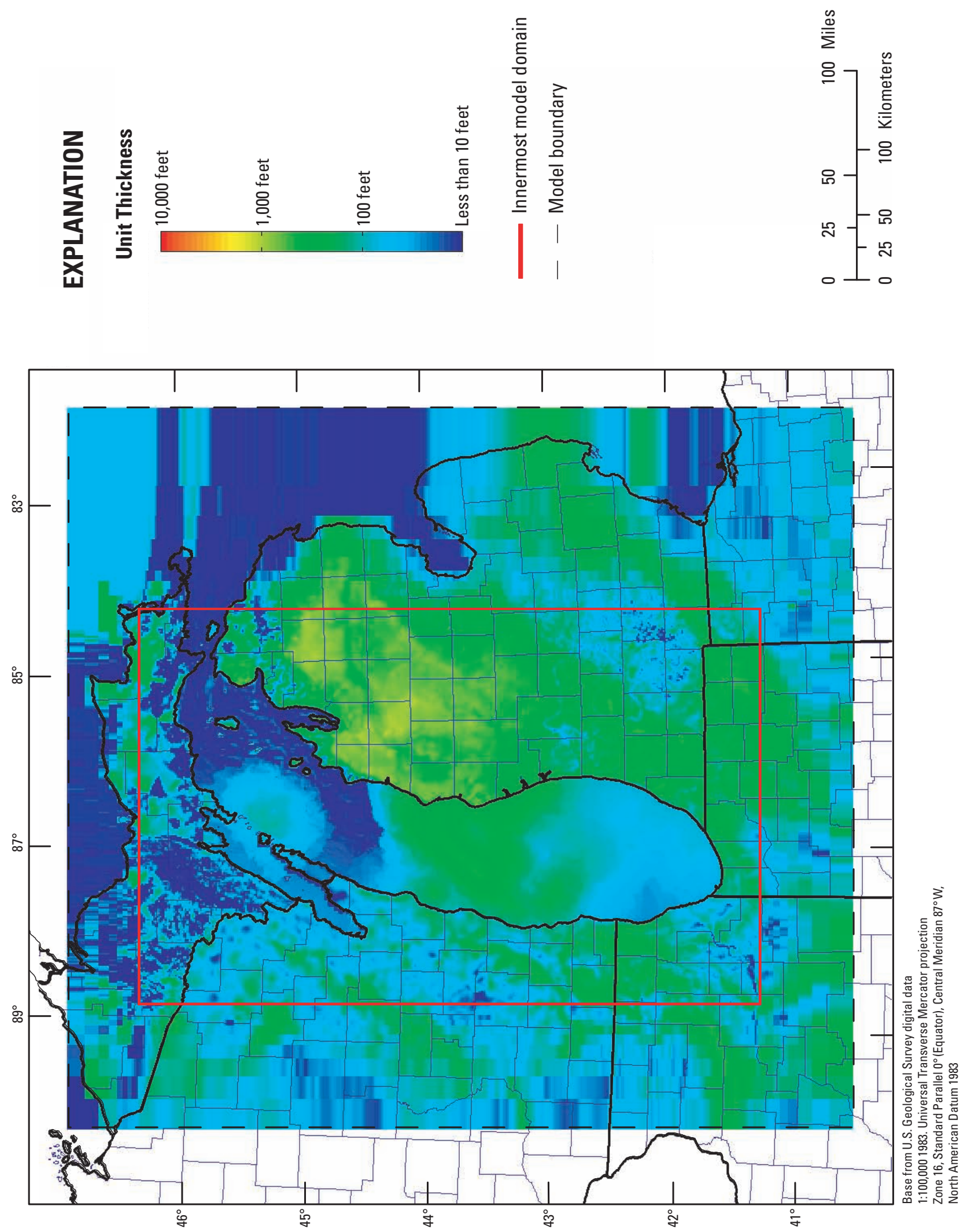

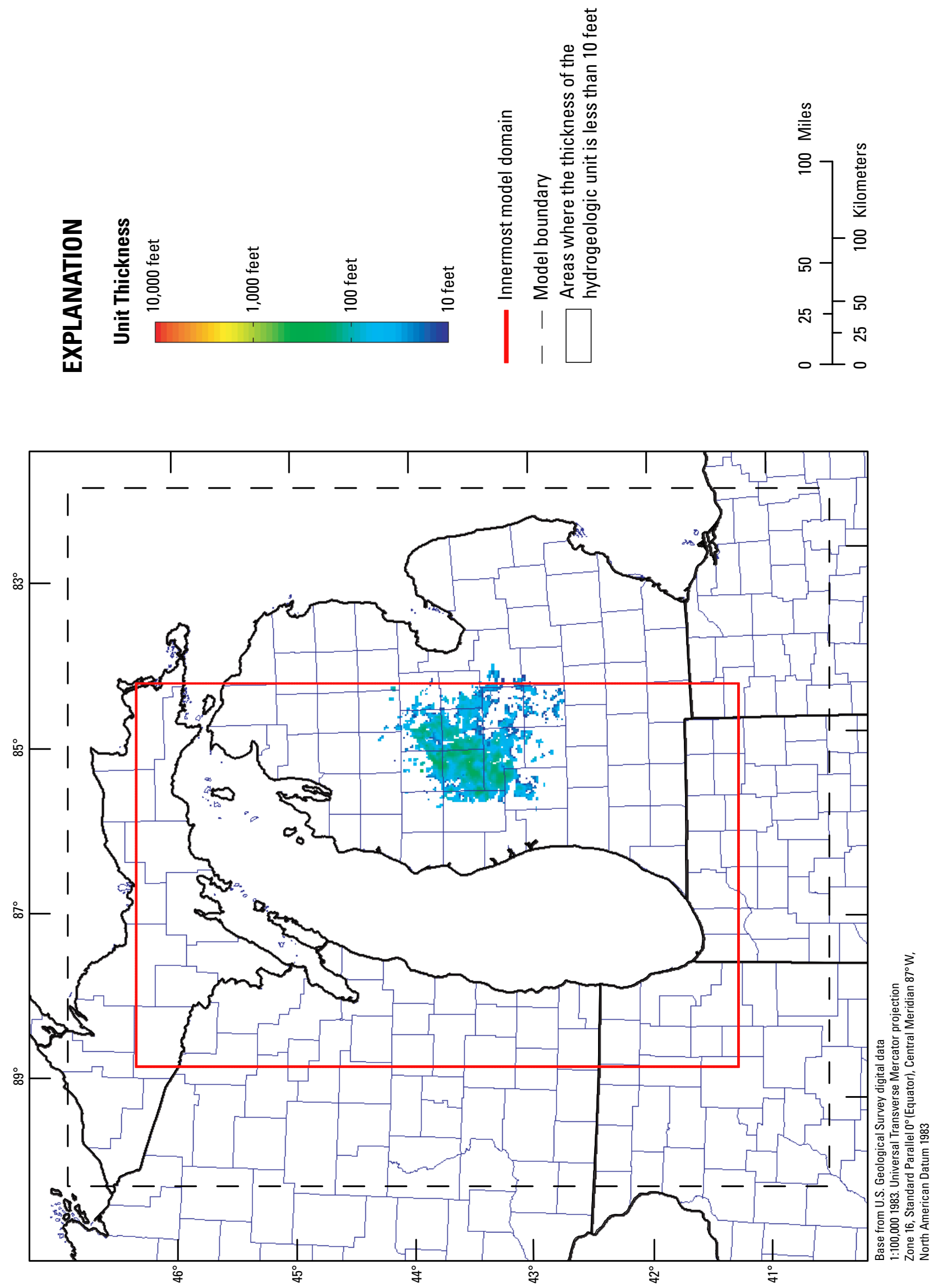

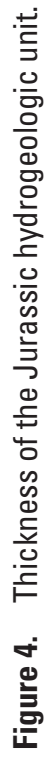



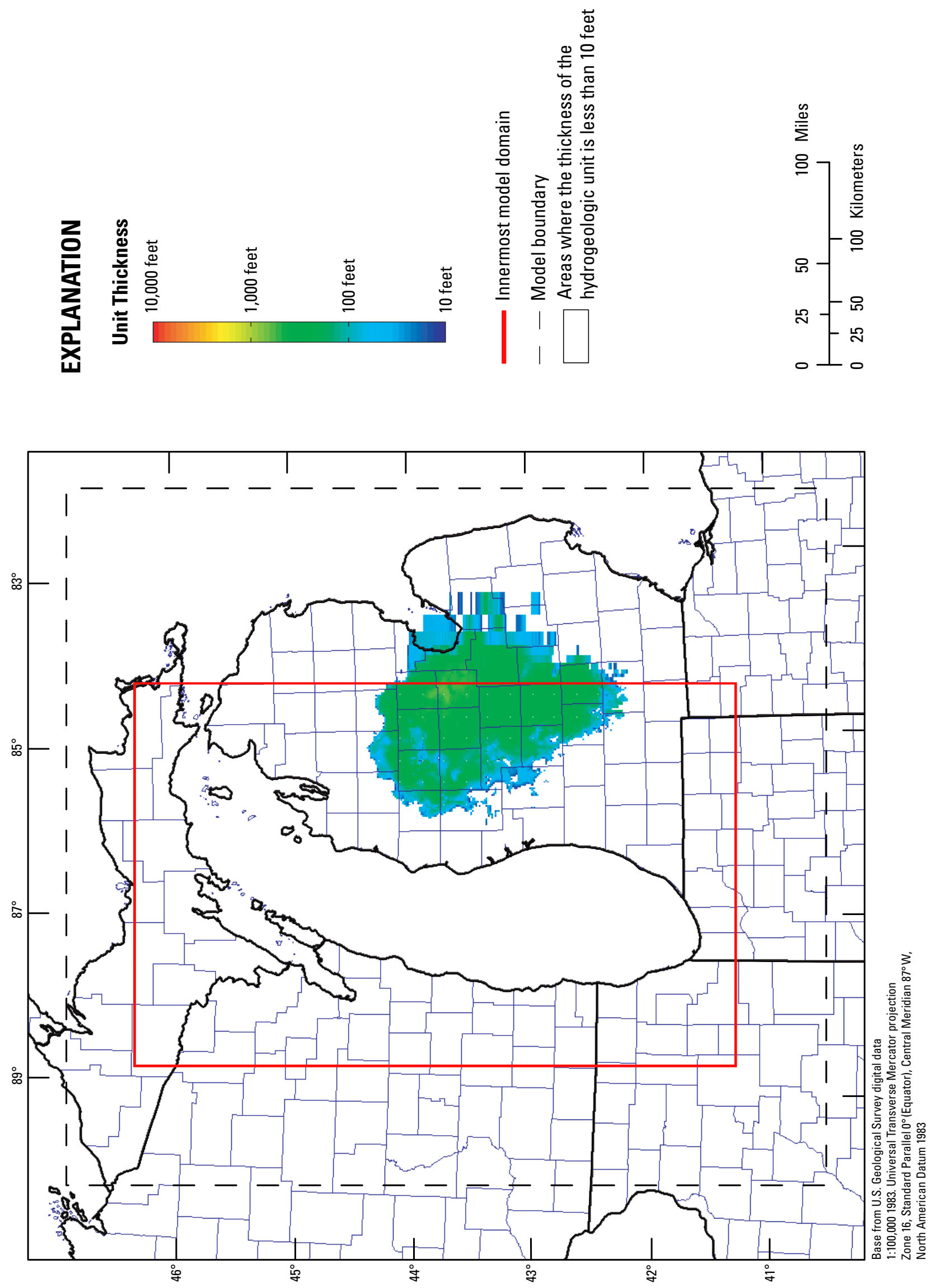

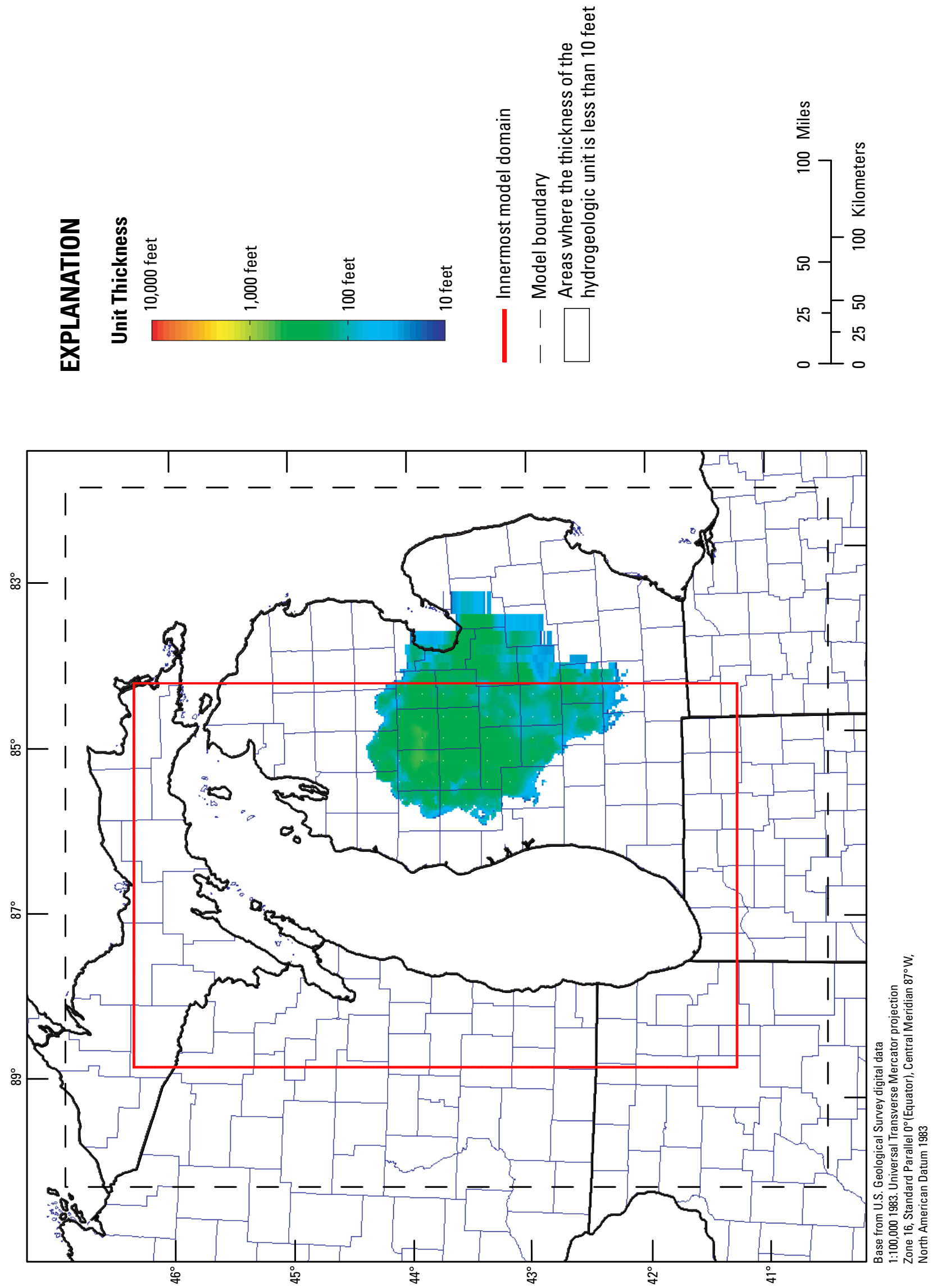

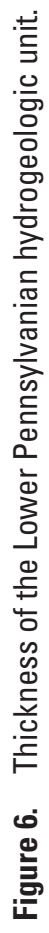



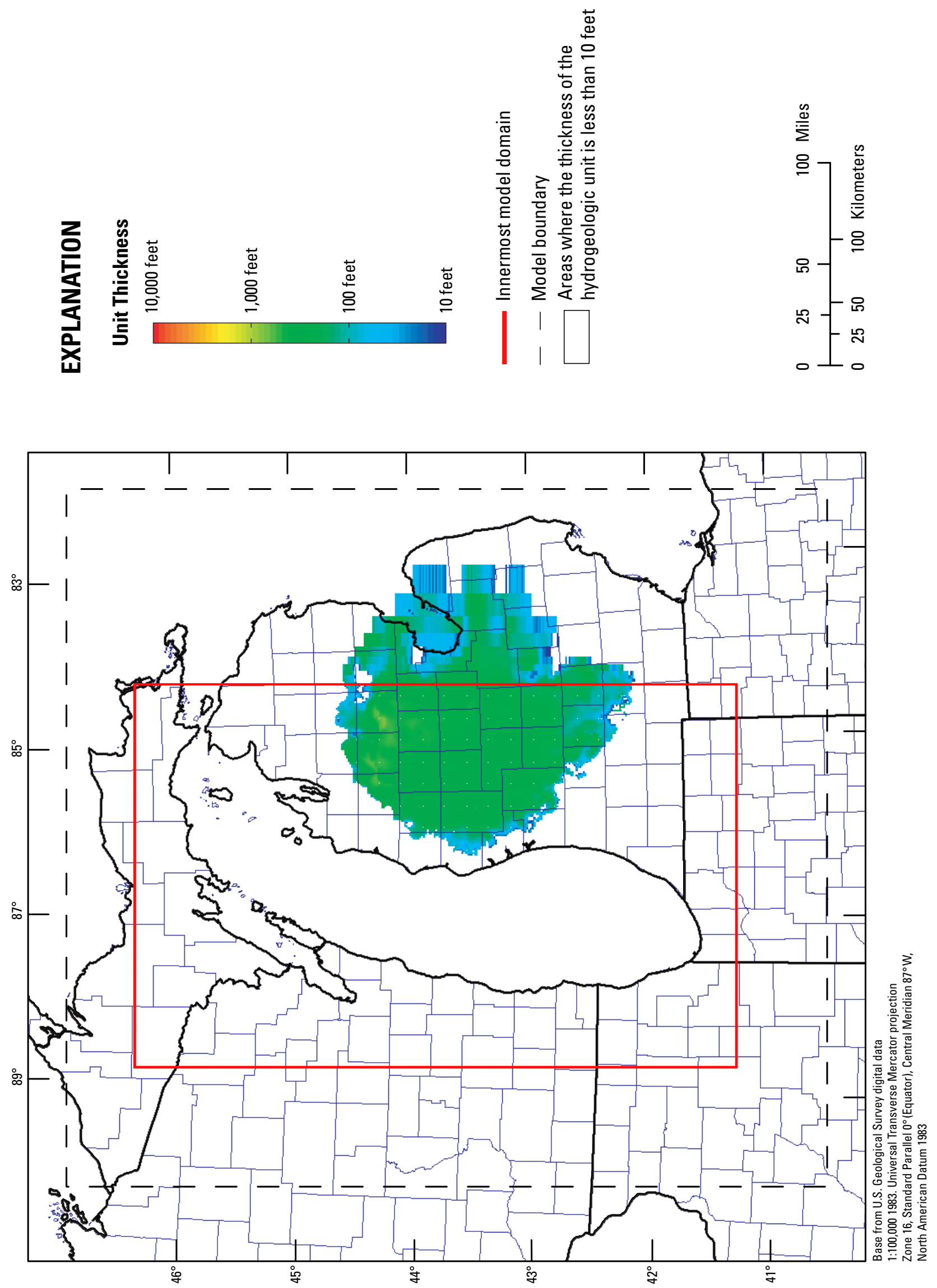

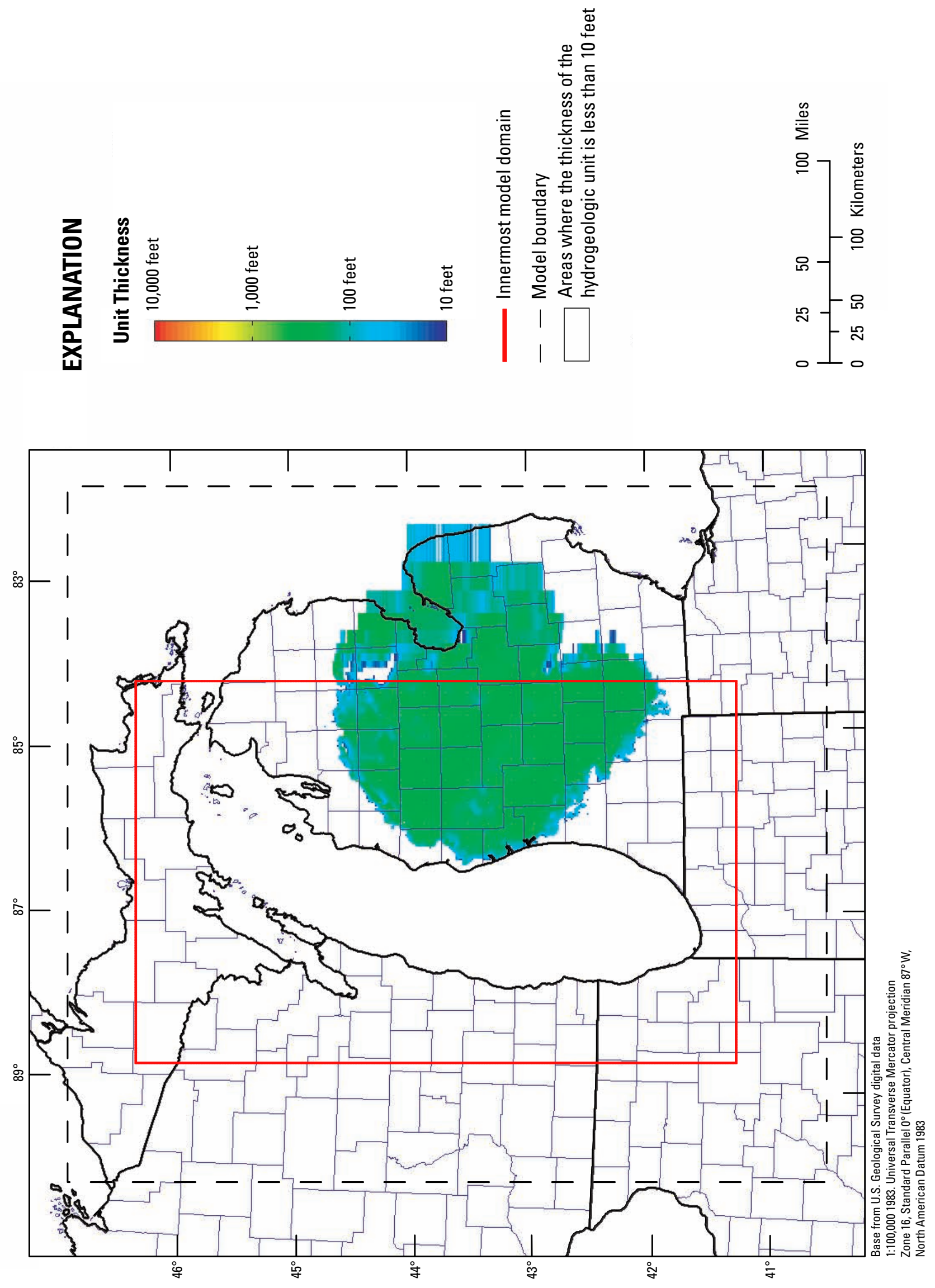

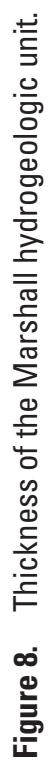



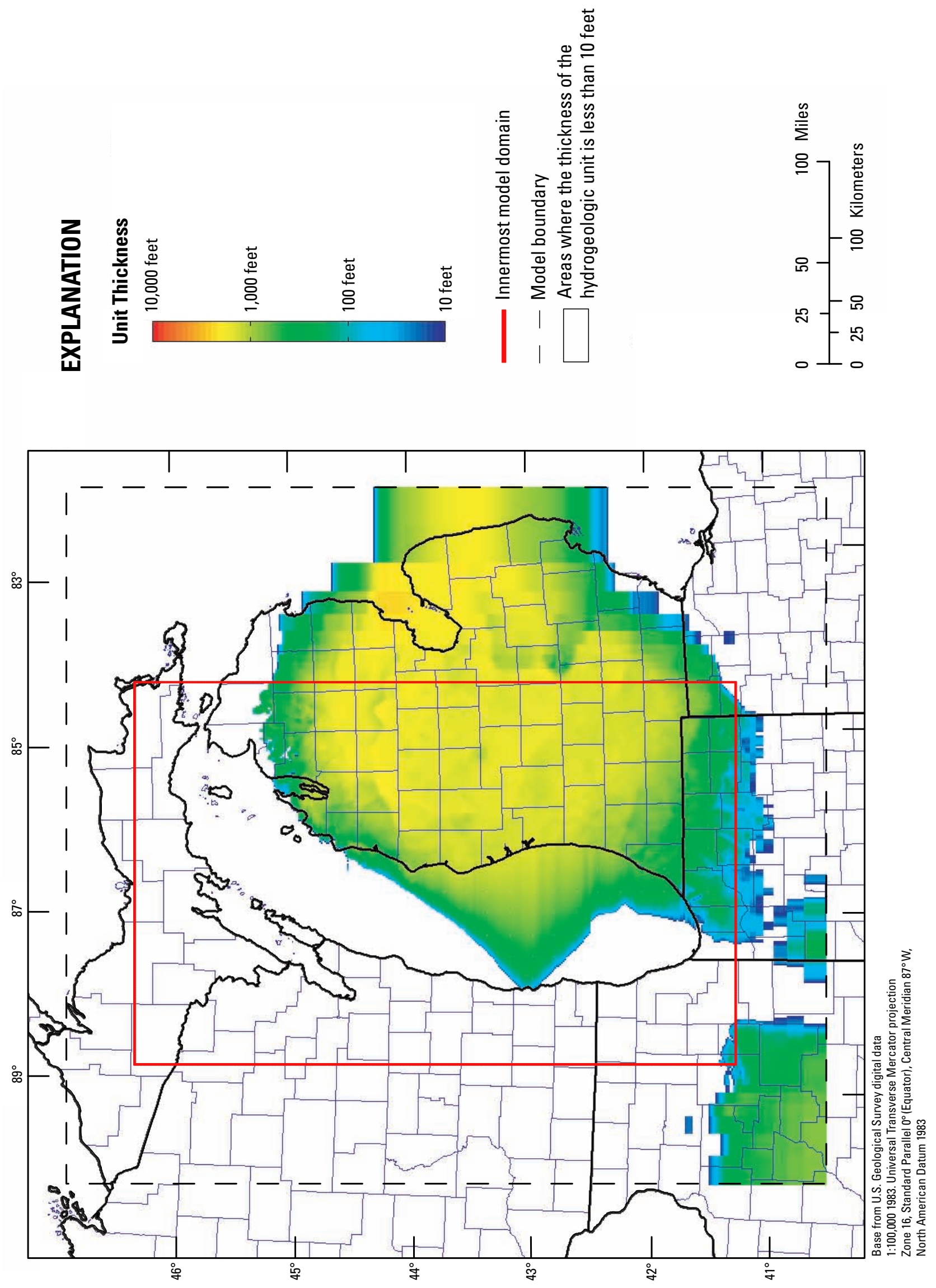





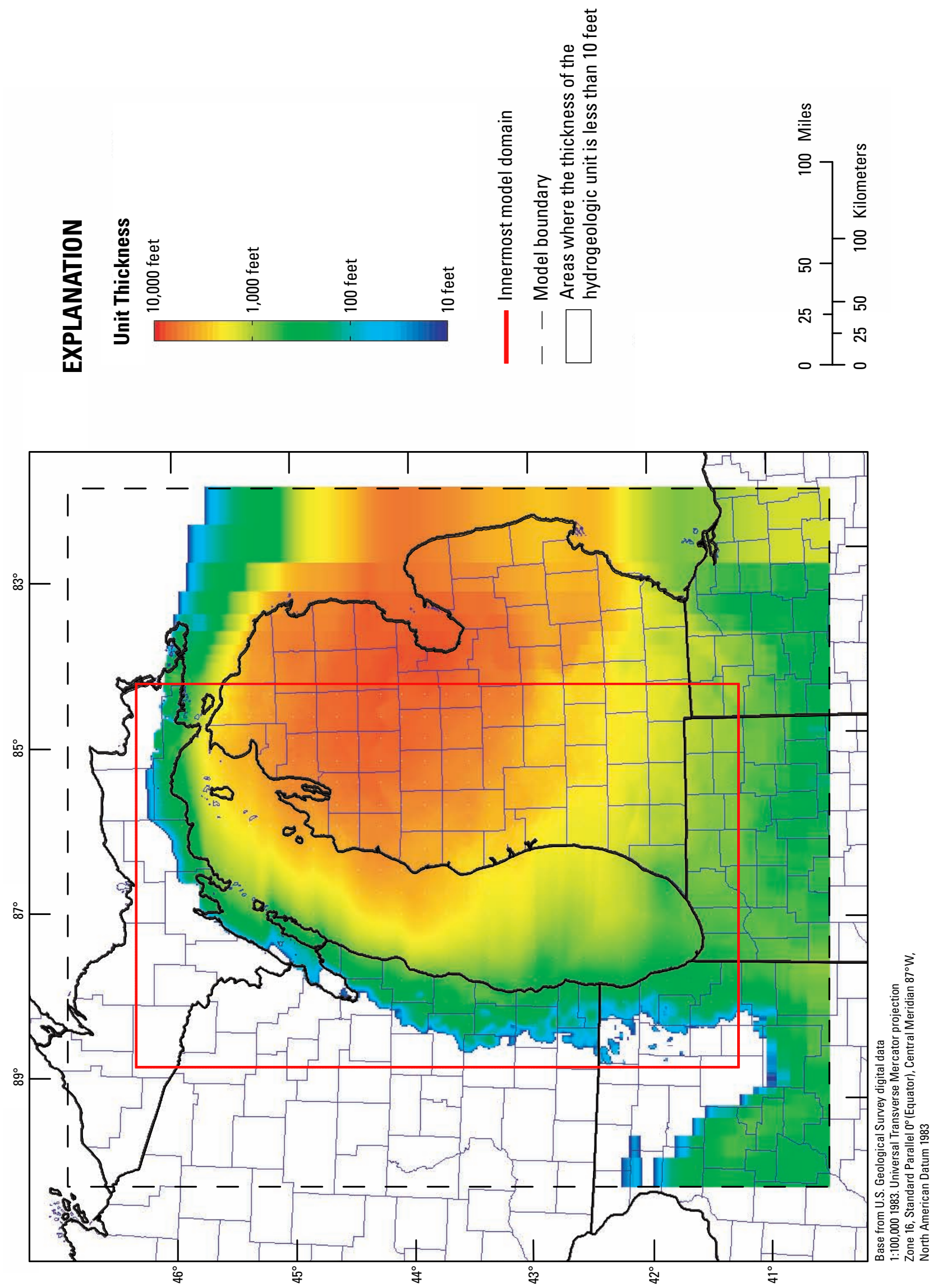

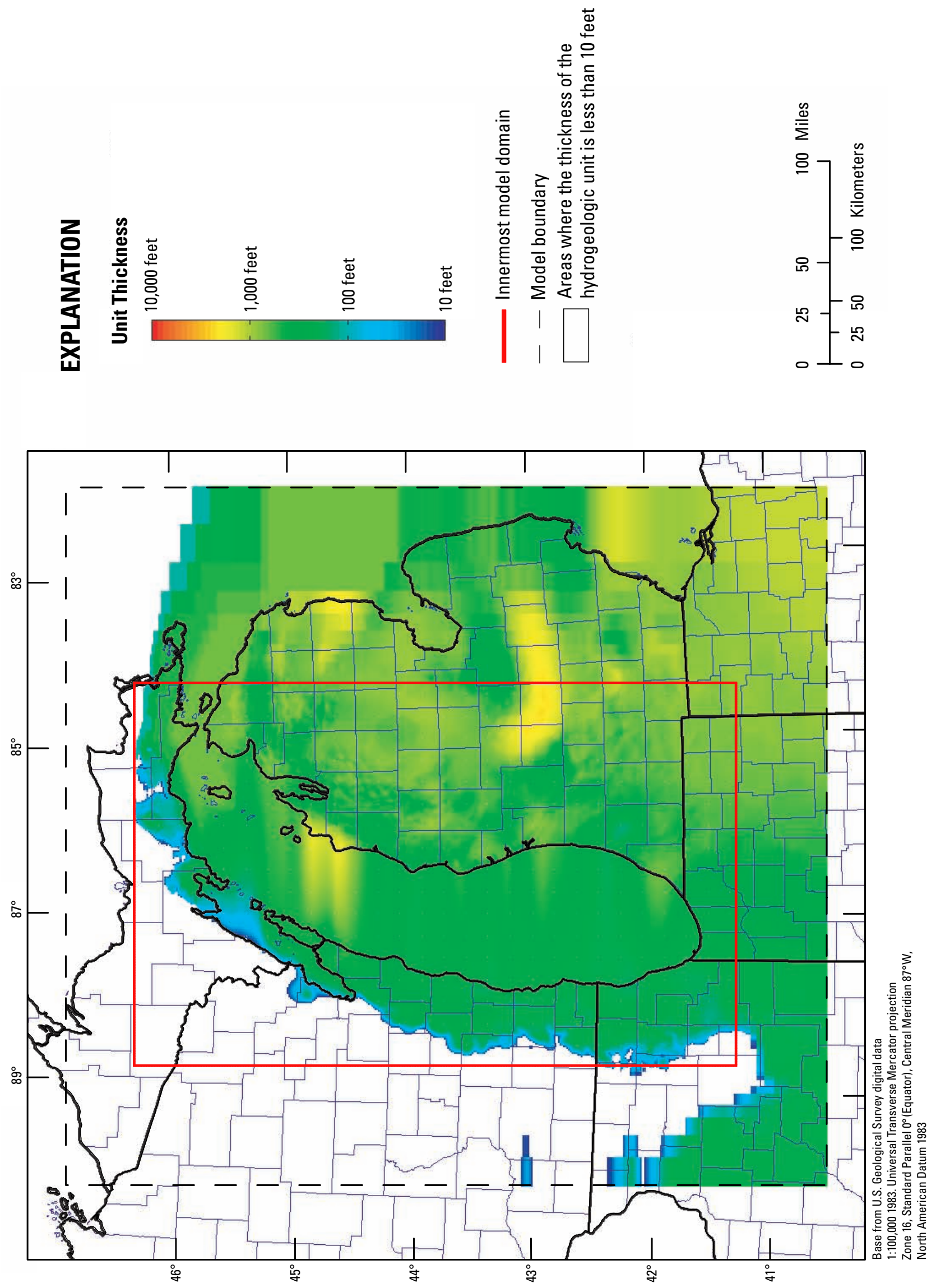

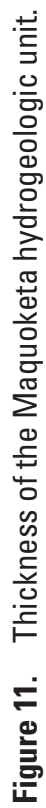





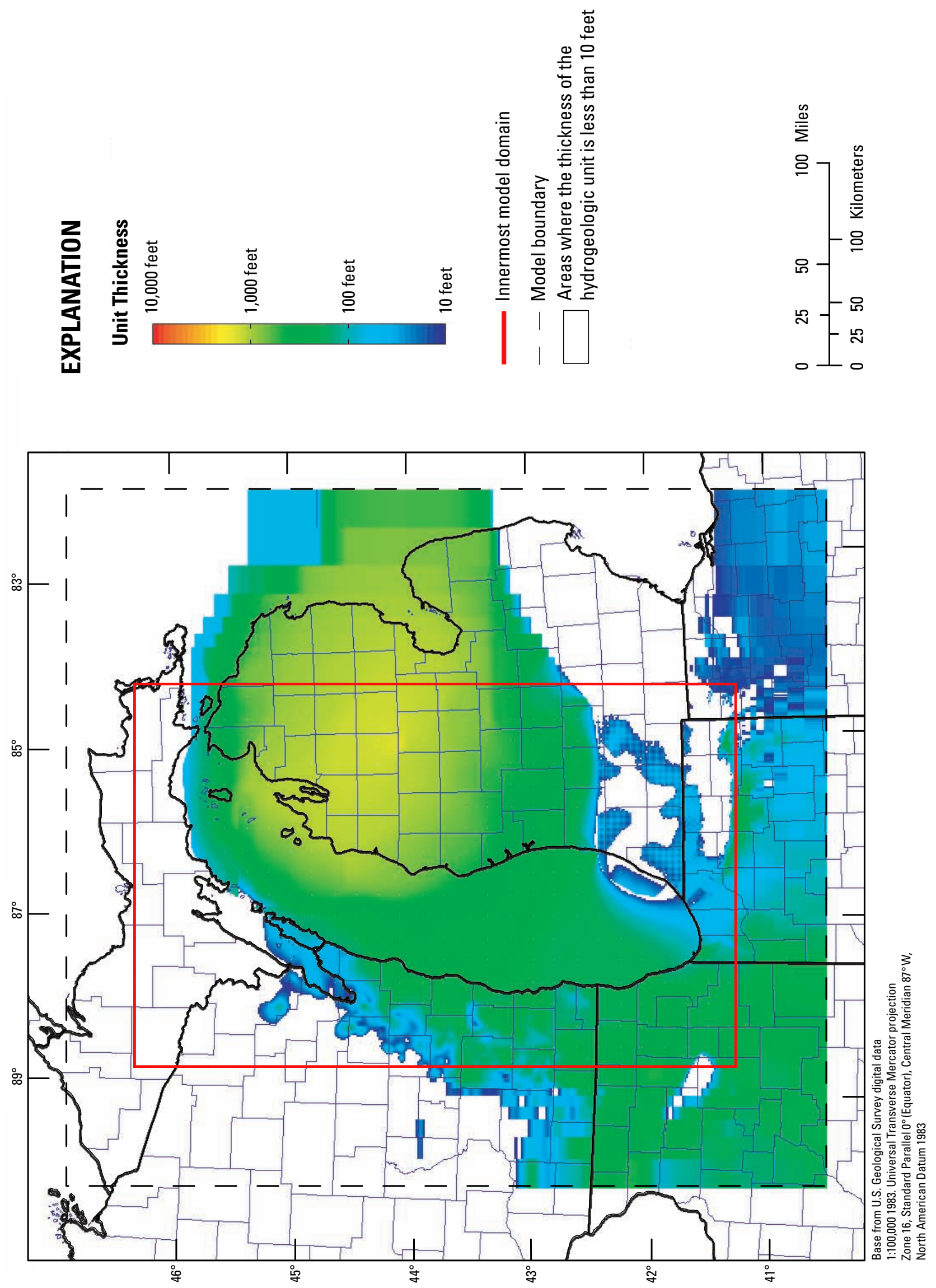

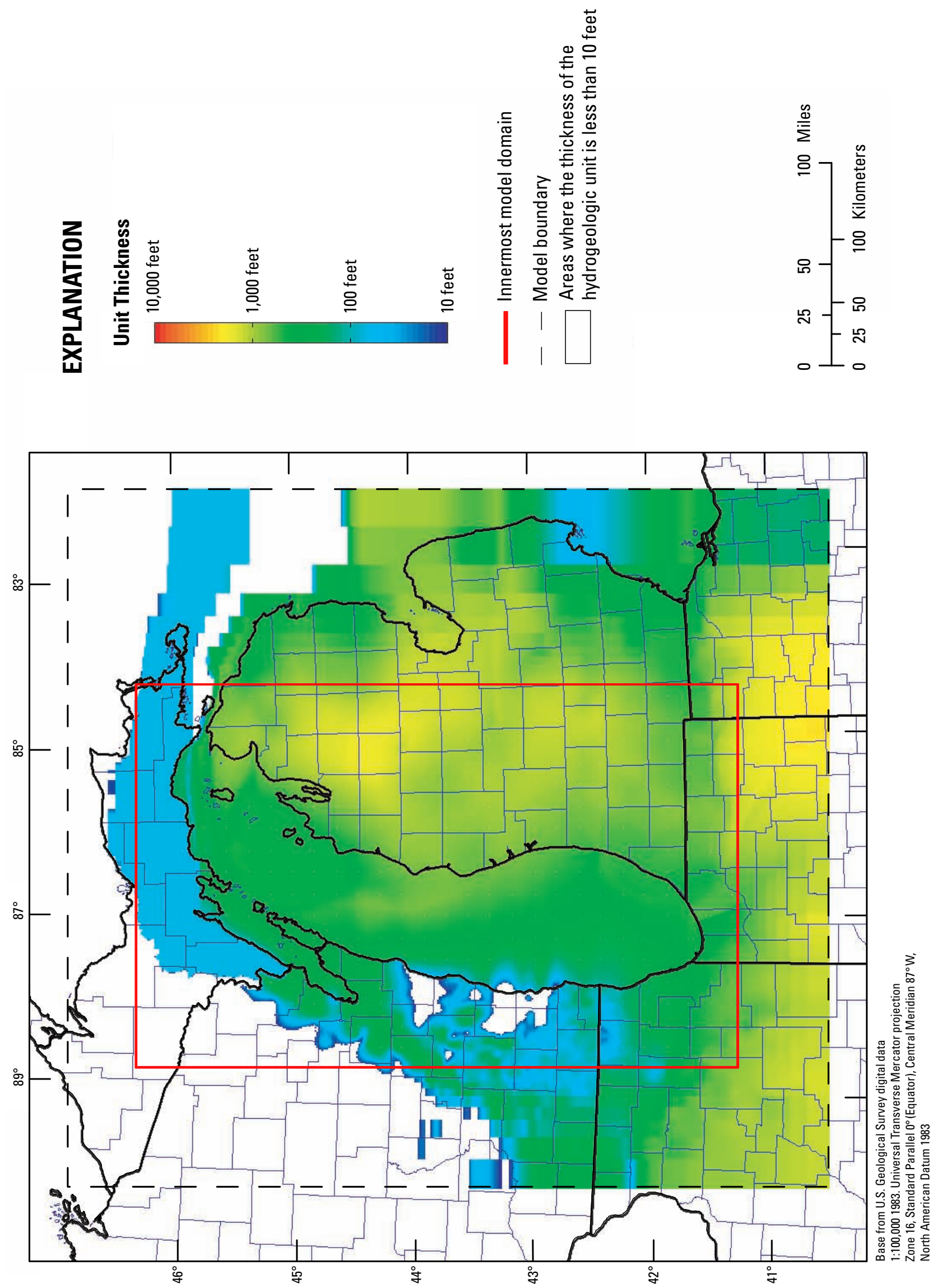

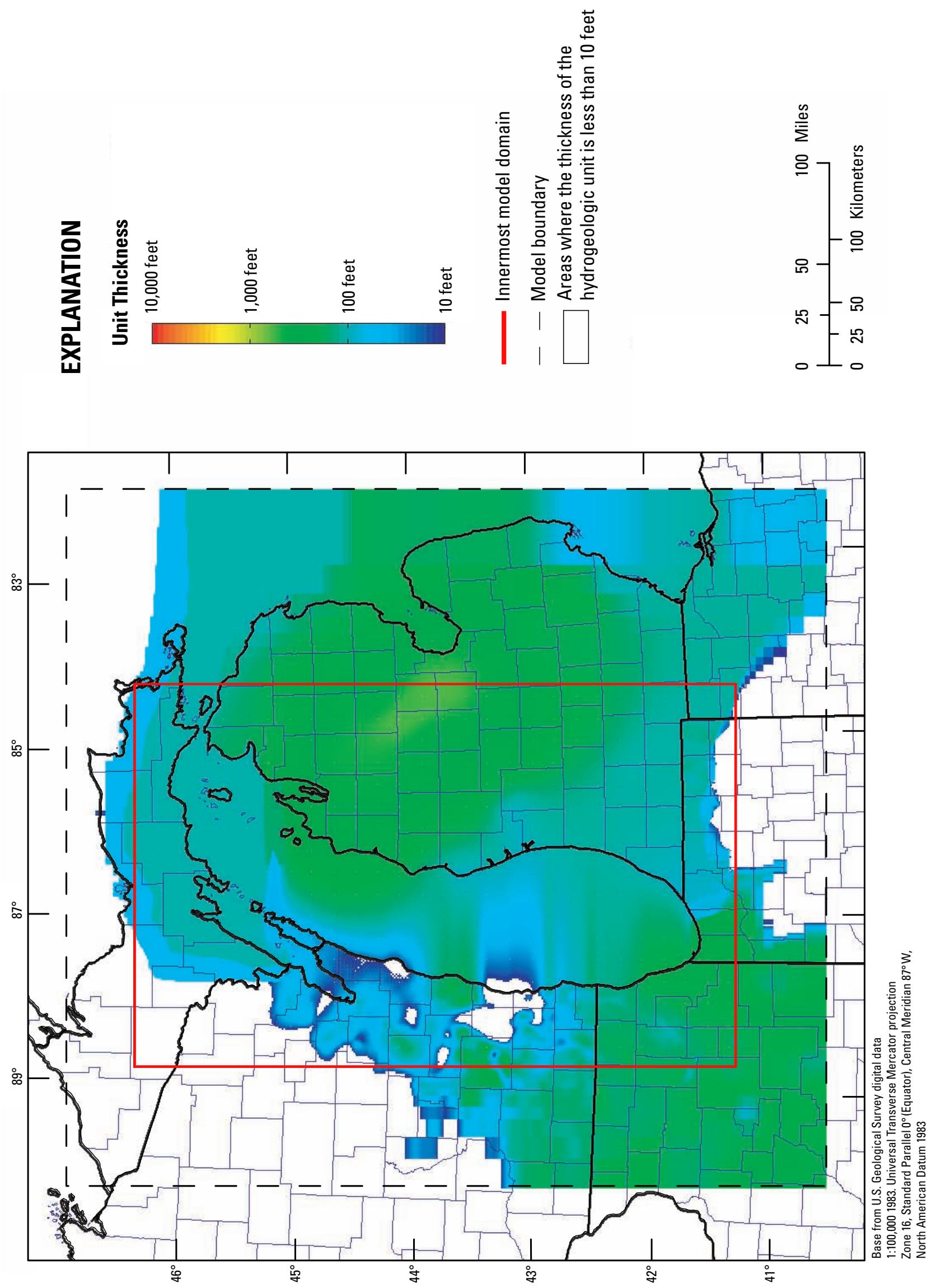

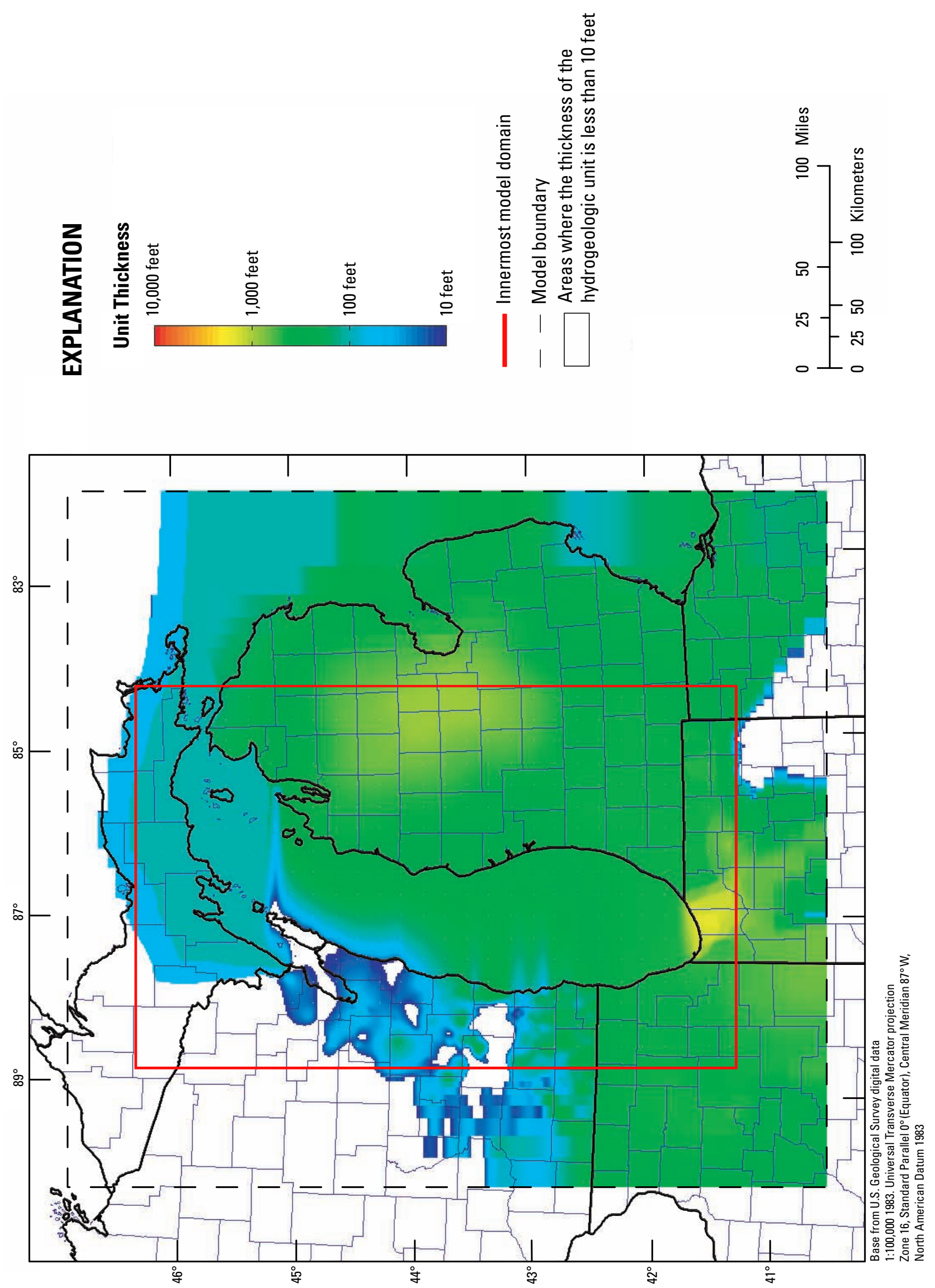

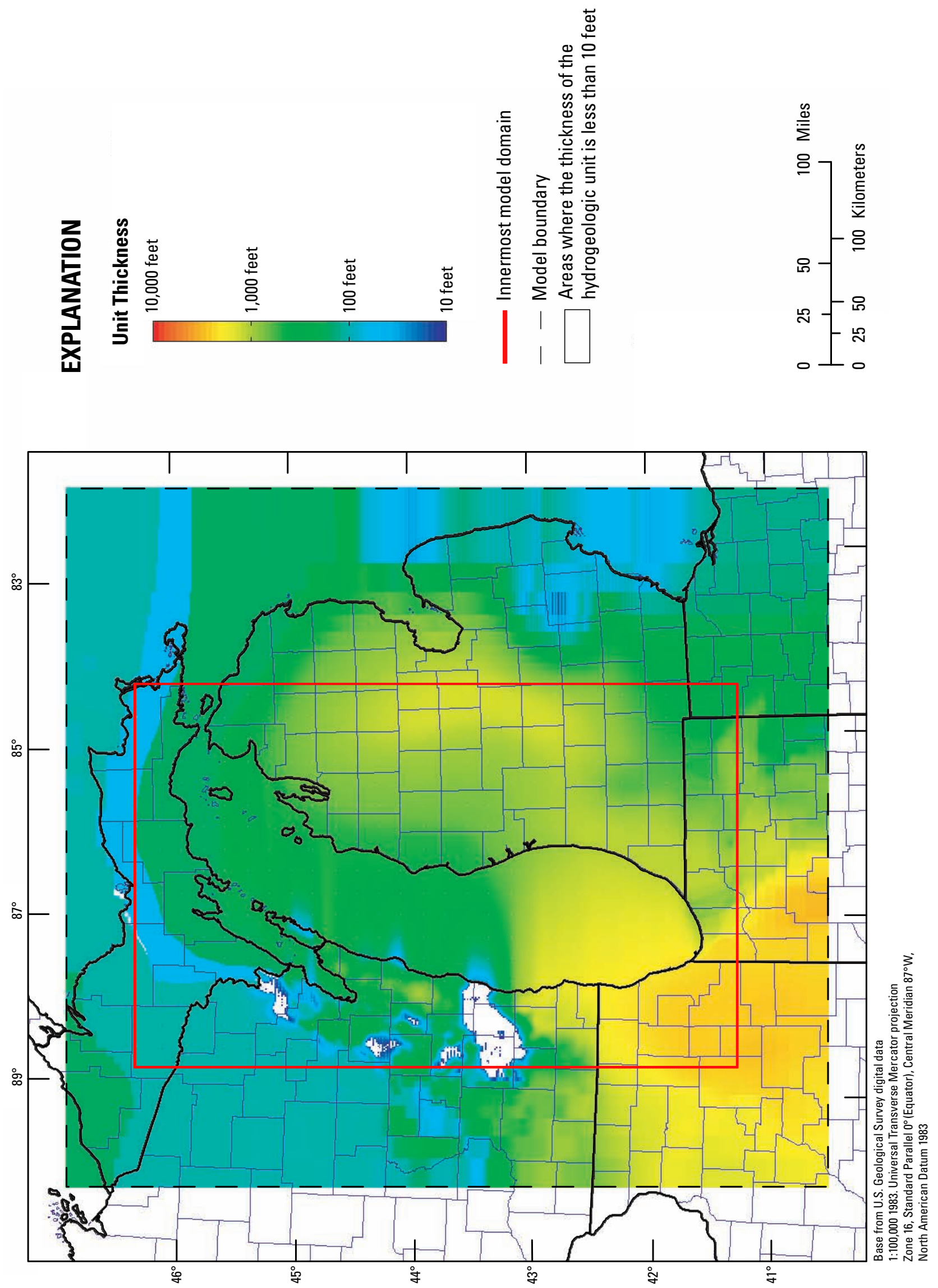


\section{Initial Salinity Distribution of Groundwater in Bedrock Hydrogeologic Units}

The use of the variable-density SEAWAT-2000 code in place of MODFLOW-2000 requires additional data including an initial or fixed distribution of salinity throughout the modeled area to account for its effect on hydraulic gradients and hydraulic conductivity. This section describes the data sources and procedures used to evaluate the initial salinity of groundwater within the Lake Michigan Basin model study area. Only data that originated from water samples or geophysical methods were used in developing the distributions. Data presented in this report are referred to as "salinity data" and are reported in terms of the concentration of total dissolved solids, which is an expression for the combined content of all inorganic and organic substances contained in a volume of water (Hem, 1985, p. 157).

\section{Sources of Groundwater Salinity Data}

Several studies have gathered data on the salinity of groundwater for parts of the Lake Michigan Basin model study area. Kammerer (1998) investigated the geology, groundwater flow, and total dissolved-solids concentrations within Wisconsin aquifers. Gupta (1993) compiled an extensive dataset of the total dissolved-solids concentrations and fluid densities for areas of Indiana, Michigan, Illinois, and Ohio. Schnoebelen and others (1995) delineated the approximate location of the 10,000-mg/L total dissolved-solids boundary in Devonian and Silurian carbonate aquifers in northern Indiana. Ryling (1961) investigated the distribution of saline water in bedrock aquifers within Wisconsin. Nicholas and others (1987) described the salinity of multiple formations at a test well in northeastern Illinois. Bond (1972) described the density of groundwater in the Mount Simon Formation in northeast Illinois and northwest Indiana. Ging and others (1996) describe the salinity of the Marshall aquifer in the Lower Peninsula of Michigan. Meissner and others (1996) describe the salinity of the Saginaw aquifer in the Lower Peninsula of Michigan. Wahrer and others (1996) describe the salinity of the glaciofluvial aquifer system in the Lower Peninsula of Michigan.

Salinity data were available for only some of the hydrogeologic units within the area of the groundwater-flow model. No data were available for the Jurassic, Lower Pennsylvanian, Michigan, Devonian-Mississippian, Maquoketa, St. Peter, Ironton-Galesville, or Eau Claire hydrogeologic units. Sources used in each State are listed in table 3.

\section{Interpolation Methods Used to Develop Initial Salinity Distribution}

Data from Gupta (1993) were reported as both the density and total dissolved-solids concentration of groundwater; however, for the state of Michigan, data were reported only in terms of density. The data points reported in both density and concentration were used to create a linear regression of the relation between the two terms (fig. 18). This regression model was used to calculate the missing concentration values based on reported density values. Concentration values of total dissolved-solids were interpolated spatially by use of a kriging interpolator available in ARC-INFO, version 8.3 (Environmental Systems Research Institute, 2003). Contours of total dissolved-solids concentration were manually drawn from the interpolated surfaces to create the initial distribution of salinity for each hydrogeologic unit with available data.

Salinity data for groundwater in the two Mount Simon model layers were created by use of total dissolved-solids concentration contours from Bond (1972) in the Illinois region of the model. Bond reports seven different distributions of concentration that vary with depth. Two distributions were selected based on the approximate depths of the two model layers that represent the Mount Simon hydrogeologic unit.

Total dissolved-solids concentrations for groundwater in the bedrock hydrogeologic units present in Wisconsin were defined by use of data from cross sections included in Kammerer (1998), and the distributions of total dissolved-solids concentrations were then compared with those reported by Ryling (1961) for similarities. Both datasets have similar distributions of groundwater salinity along the western shoreline of Lake Michigan and areas around Lake Winnebago. Much of the salinity in the Wisconsin part of the study area is less than $1,000 \mathrm{mg} / \mathrm{L}$ for all of the model layers. Concentrations greater than $1,000 \mathrm{mg} / \mathrm{L}$ were digitized and included in the salinity dataset.

Contour datasets of groundwater salinity for each hydrogeologic unit with available data were combined by use of the ARC-INFO GIS and spatially interpolated using the kriging interpolator (Environmental Systems Research Institute, 2003). These distributions were then assigned to the model layers corresponding to the hydrogeologic unit (fig. 2). Because the vertical distribution of salinity is inconsistent, it was necessary to either interpolate data between model layers with reported salinity and those without, or assign salinity values from a layer with similar hydrogeologic properties. Table 4 shows where data were available and how data were assigned or interpolated vertically from known to unknown locations. Although the distributions for model layers 2 and 3 were taken from model layer 1, the maximum total dissolvedsolids concentrations vary due to the extent of the model layers. The distributions for each model layer were converted into ASCII format text files that list the total dissolved-solids 
concentration of each cell in the specific model layer of the groundwater-flow model. These values were then imported into the groundwater flow model.

Figures 19-38 display the total dissolved-solids concentration values for each layer of the model. Because the distribution of total dissolved-solids values vary by several orders of magnitude, the scales present on the figures vary. Model layers in the Quaternary, Jurassic, Upper Pennsylvanian, Lower Pennsylvanian, and Michigan hydrogeologic units have total dissolved-solids concentrations less than 100,000 mg/L. Model layers in the Silurian-Devonian, Sinnipee, St. Peter, Prairie du Chien-Franconia, and Ironton-Galesville hydrogeologic units have total dissolved-solids concentrations greater than $400,000 \mathrm{mg} / \mathrm{L}$.

Table 3. Sources of salinity data for each State in the study area.

\begin{tabular}{ll}
\hline \multicolumn{1}{c}{ State } & \multicolumn{1}{c}{ Sources } \\
\hline Illinois & Bond (1972), Visocky and others (1985), Young (1992) \\
Indiana & Eberts and George (2000), Gupta (1993), Schnoebelen and others (1998) \\
Michigan & Ging and others (1996), Gupta (1993), Meissner and others (1996), Wahrer and others (1996) \\
Ohio & Gupta (1993) \\
Wisconsin & Kammerer (1998), Ryling (1961), Young (1992) \\
\hline
\end{tabular}

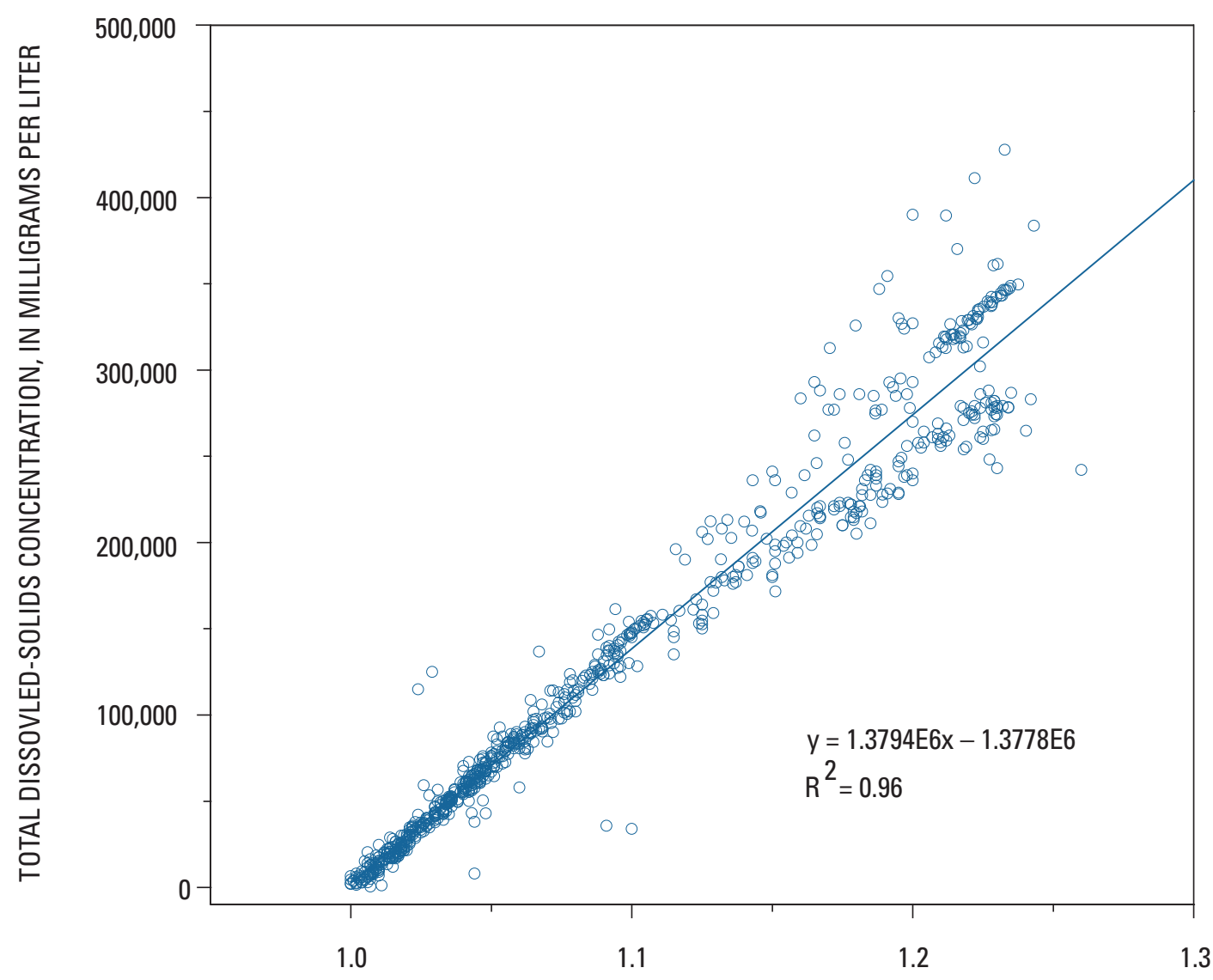

GROUNDWATER DENSITY, IN KILOGRAMS PER CUBIC METER

Figure 18. Groundwater density and total dissolved-solids concentrations for data from Gupta (1993). The equation of the best fit line was used to determine the concentration of total dissolved solids for the data where only groundwater density was reported. 

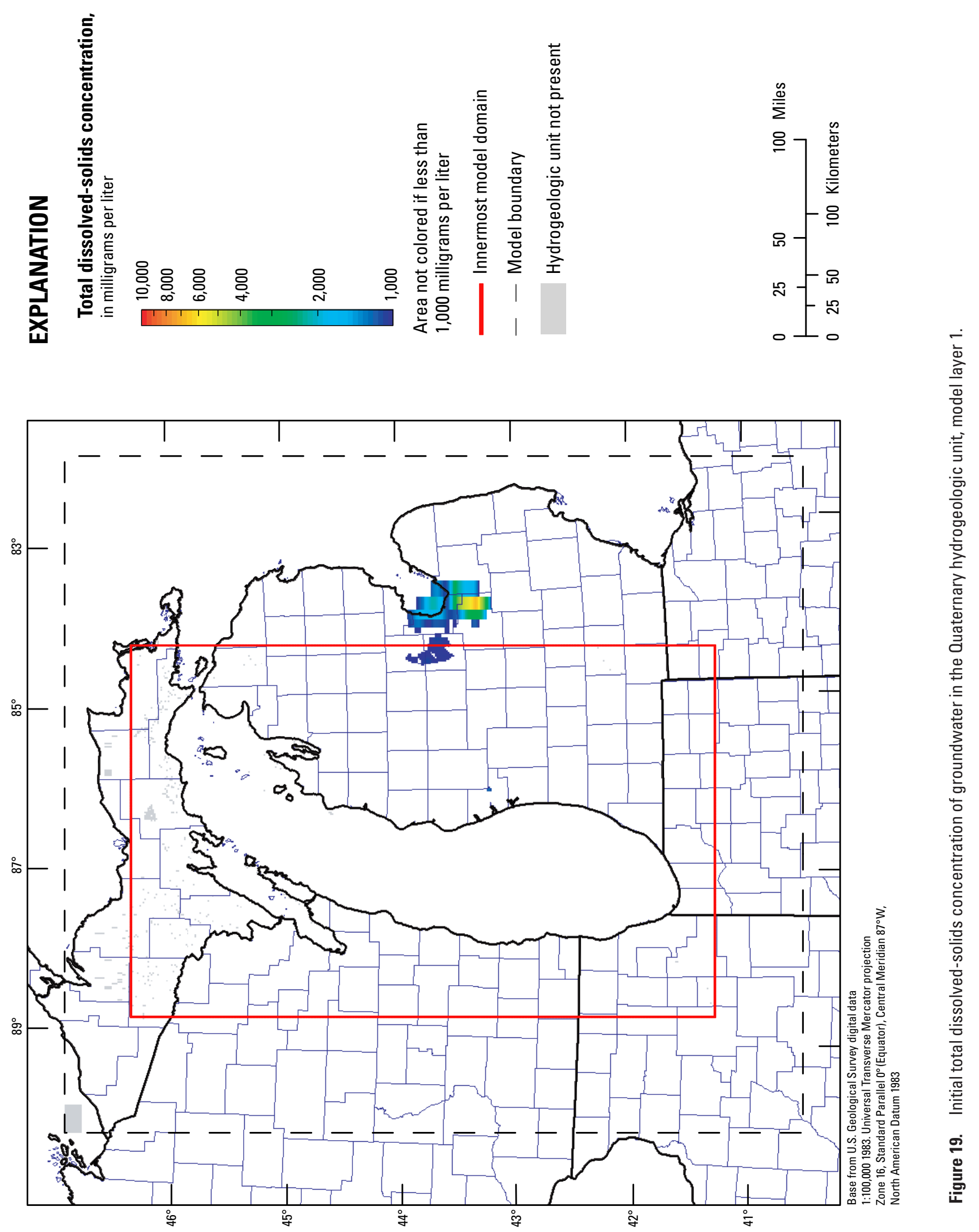

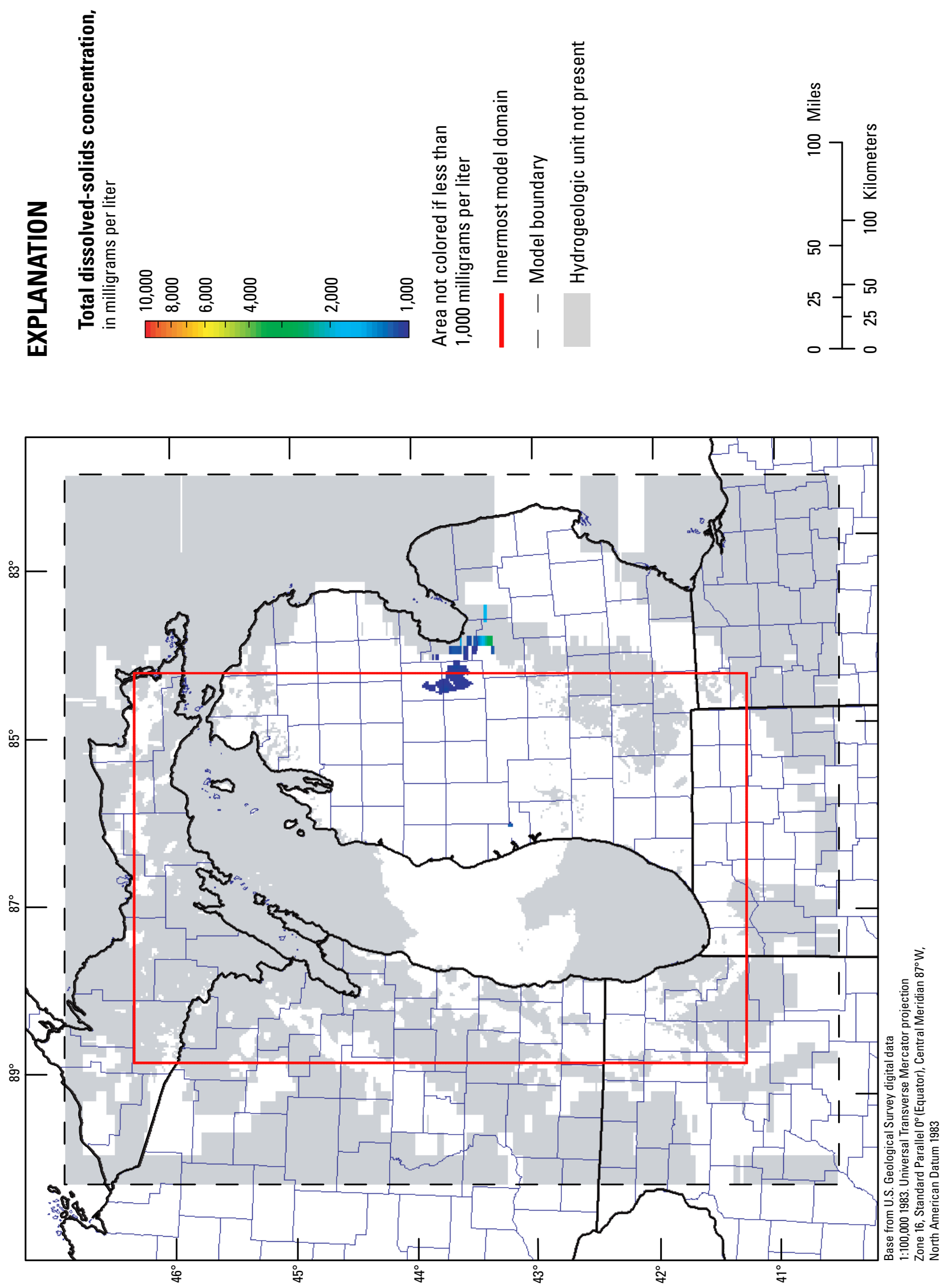

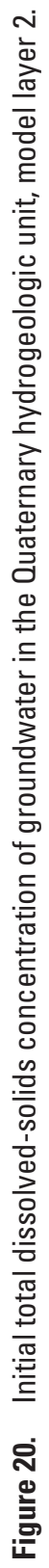



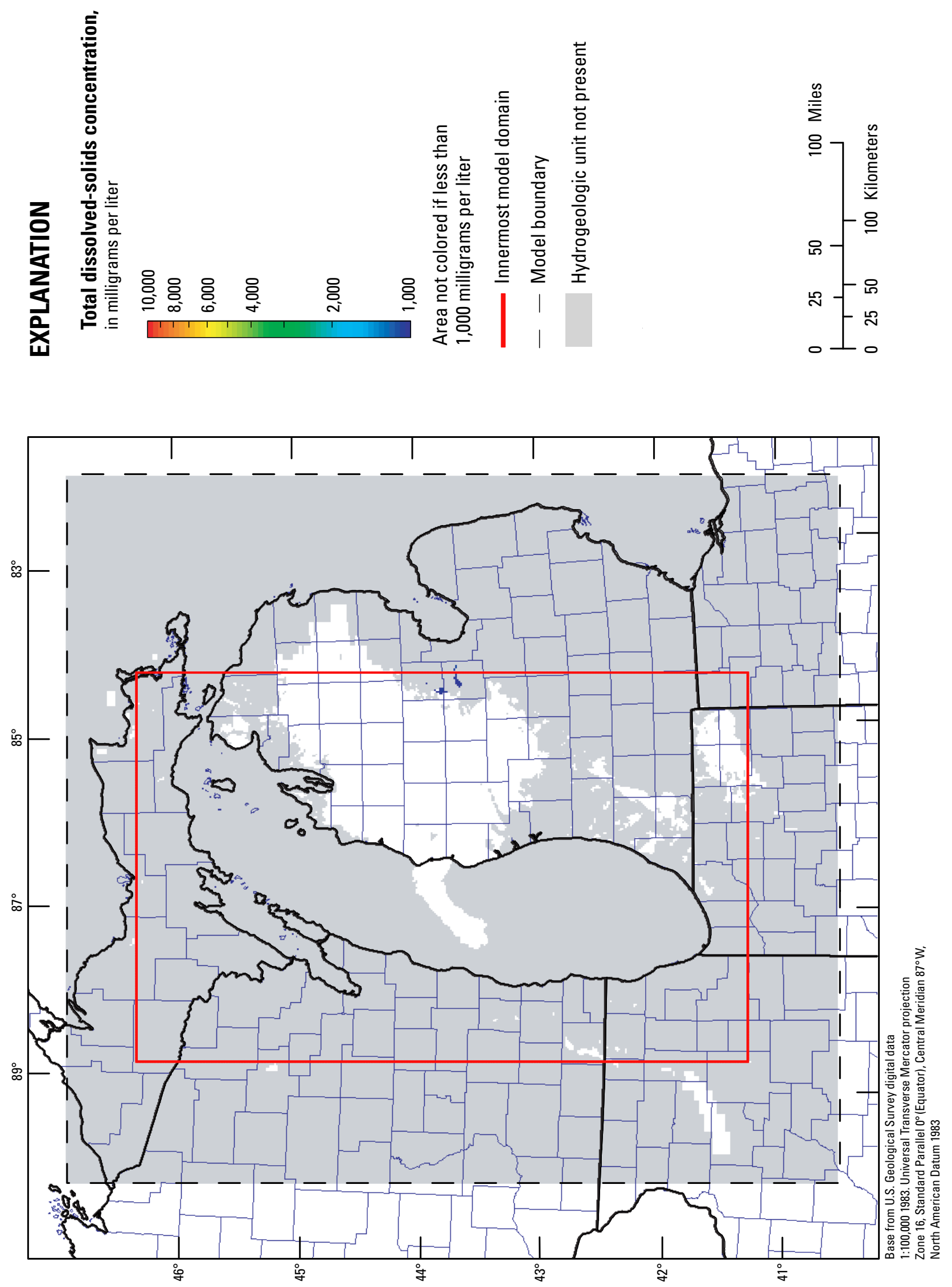

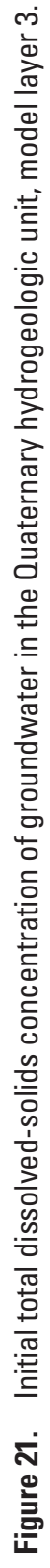



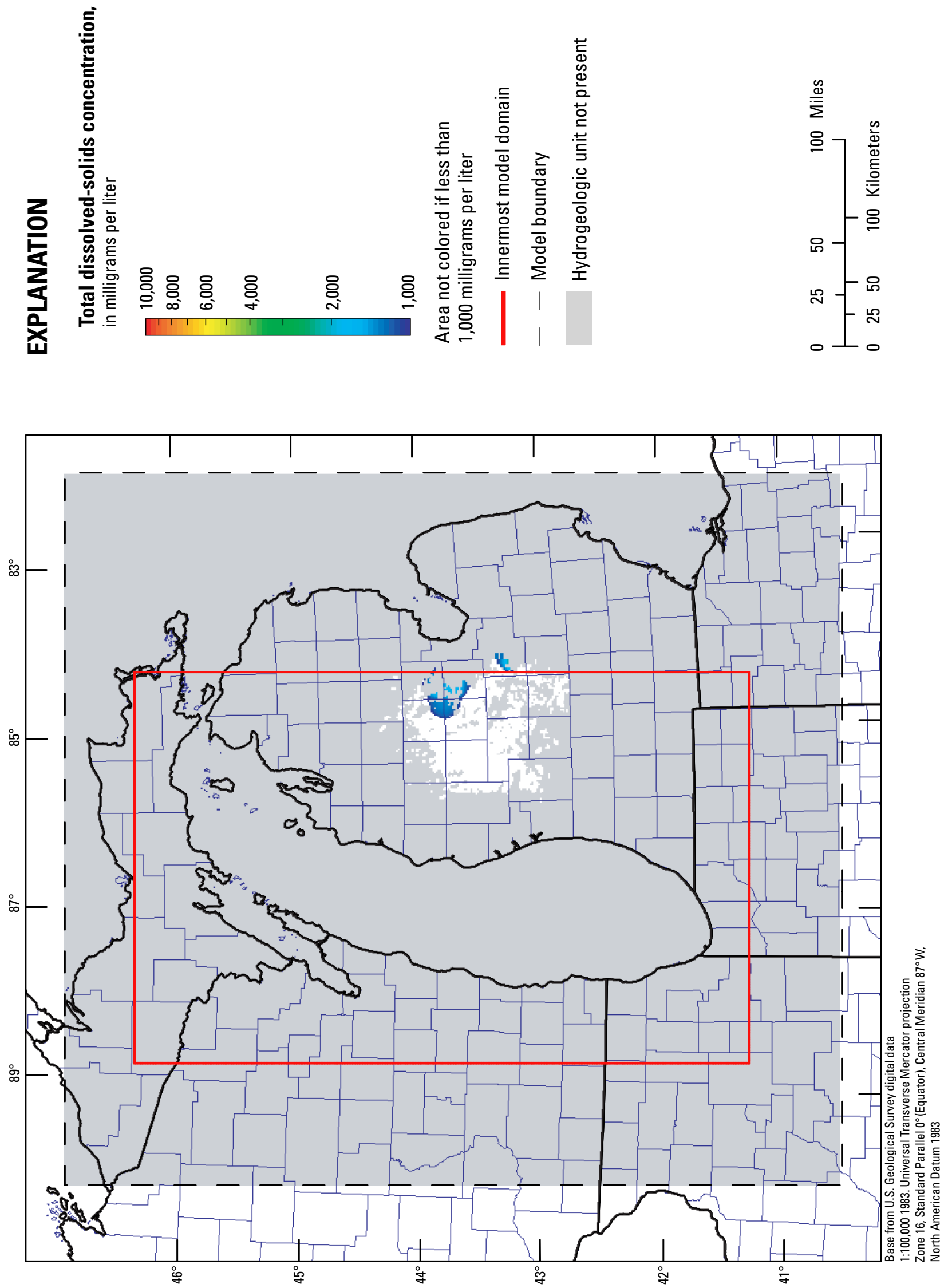





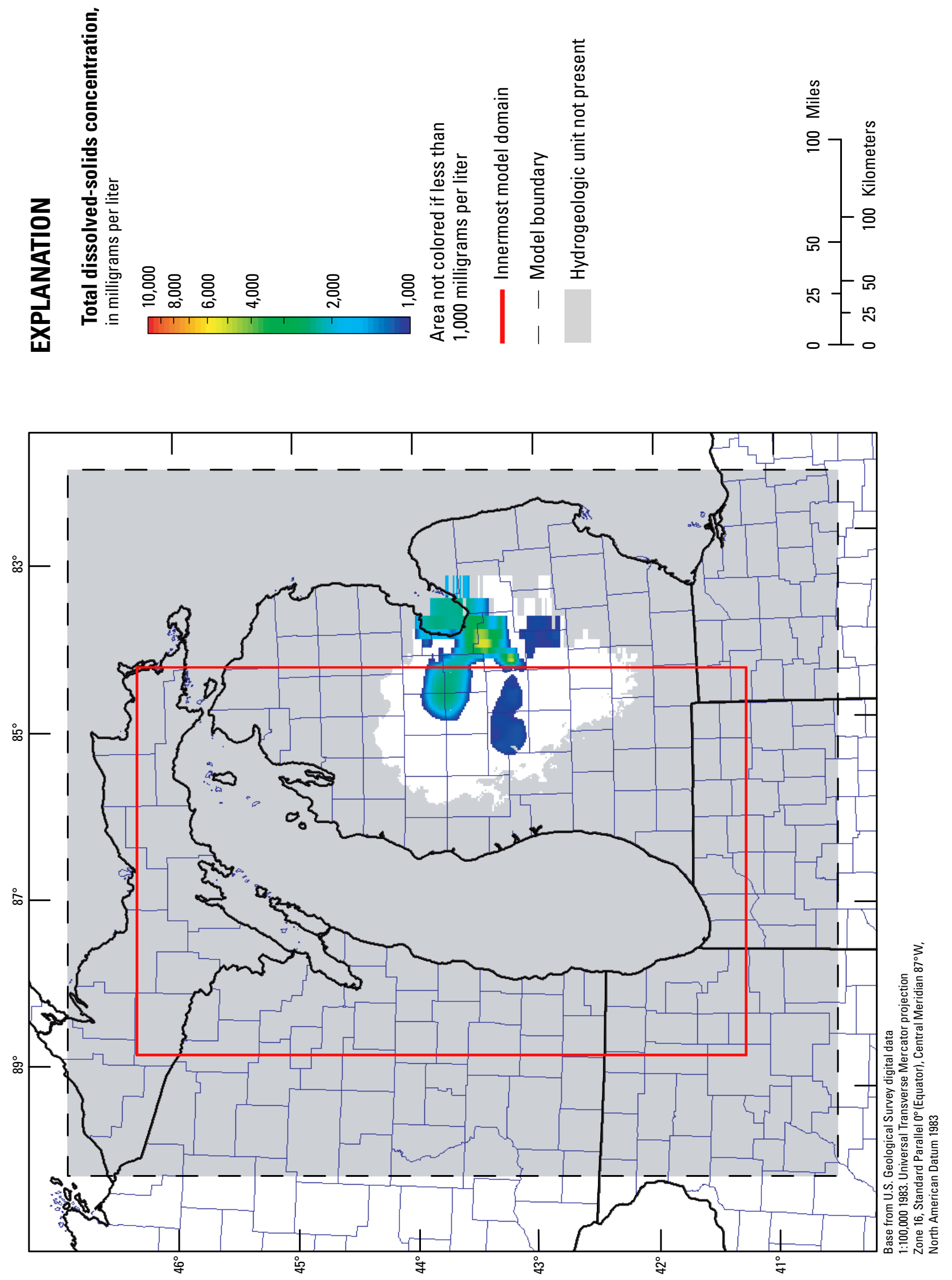





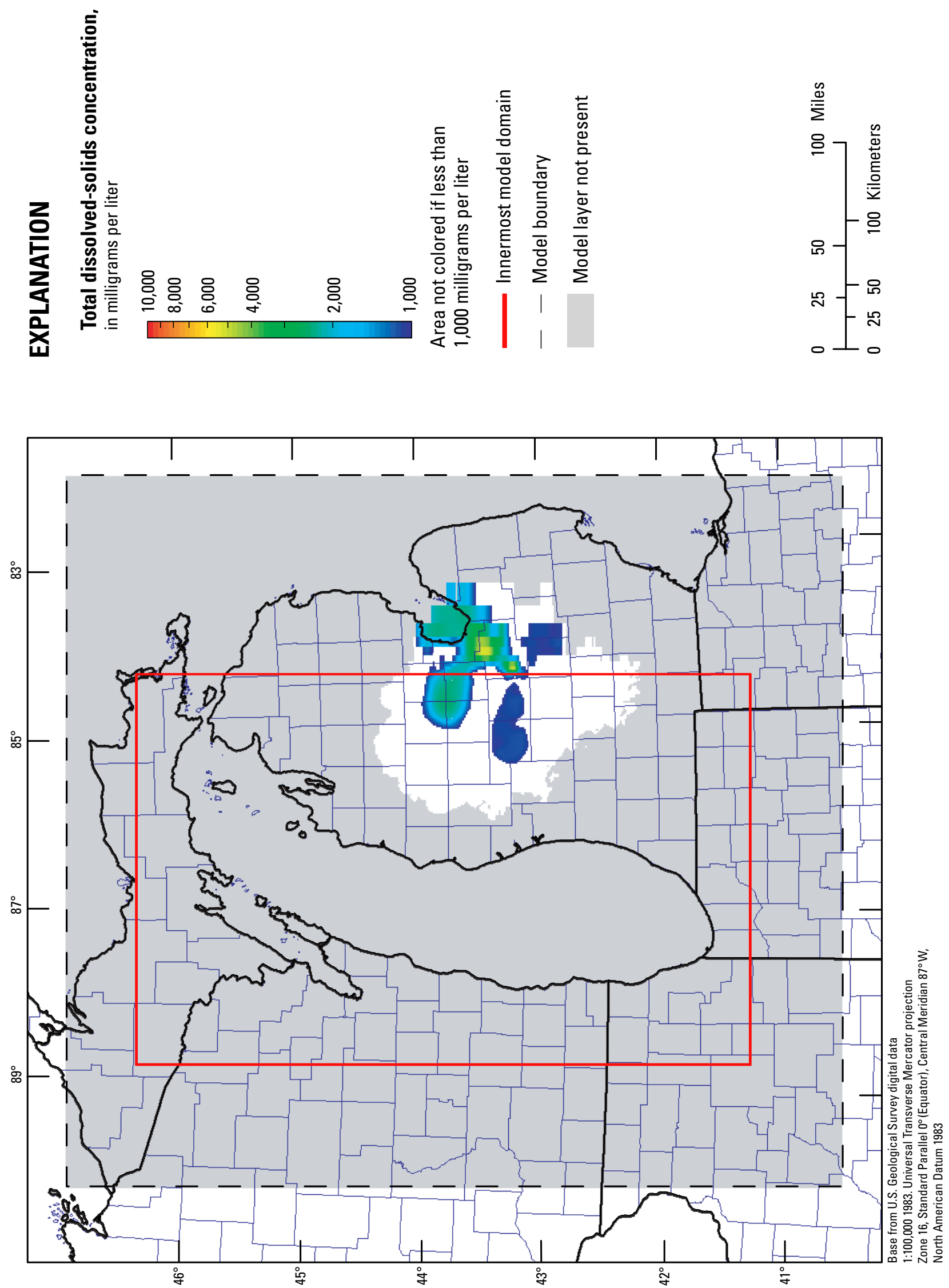





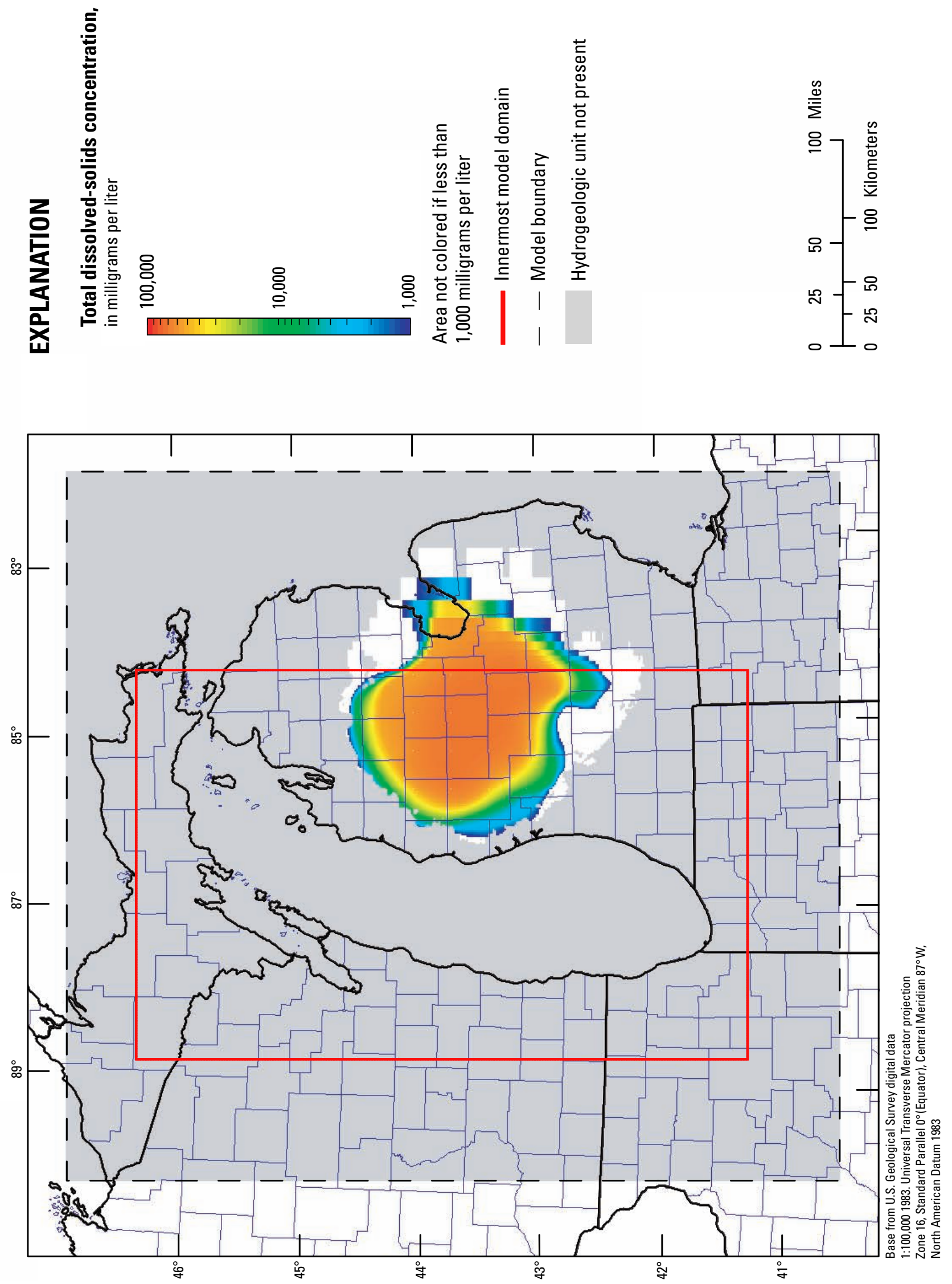

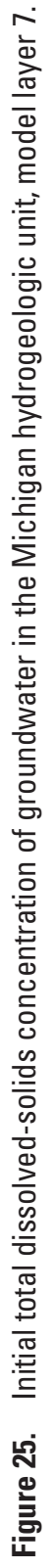





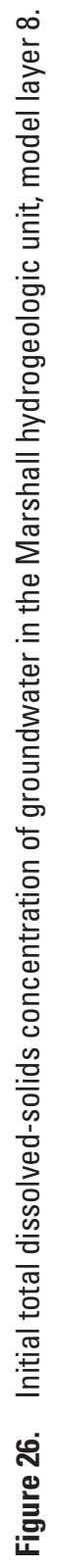



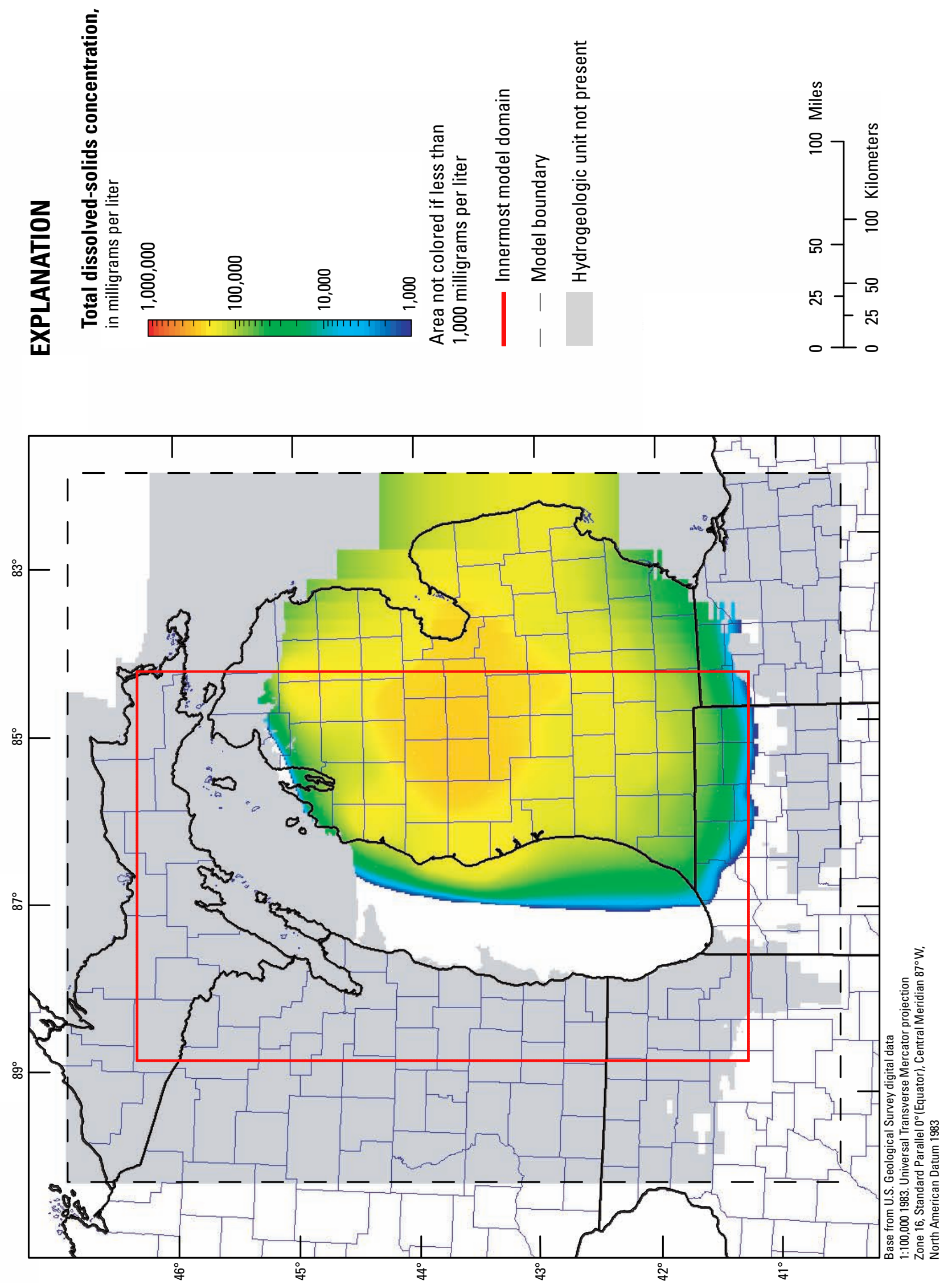

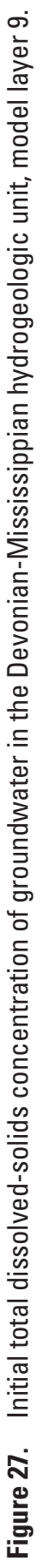



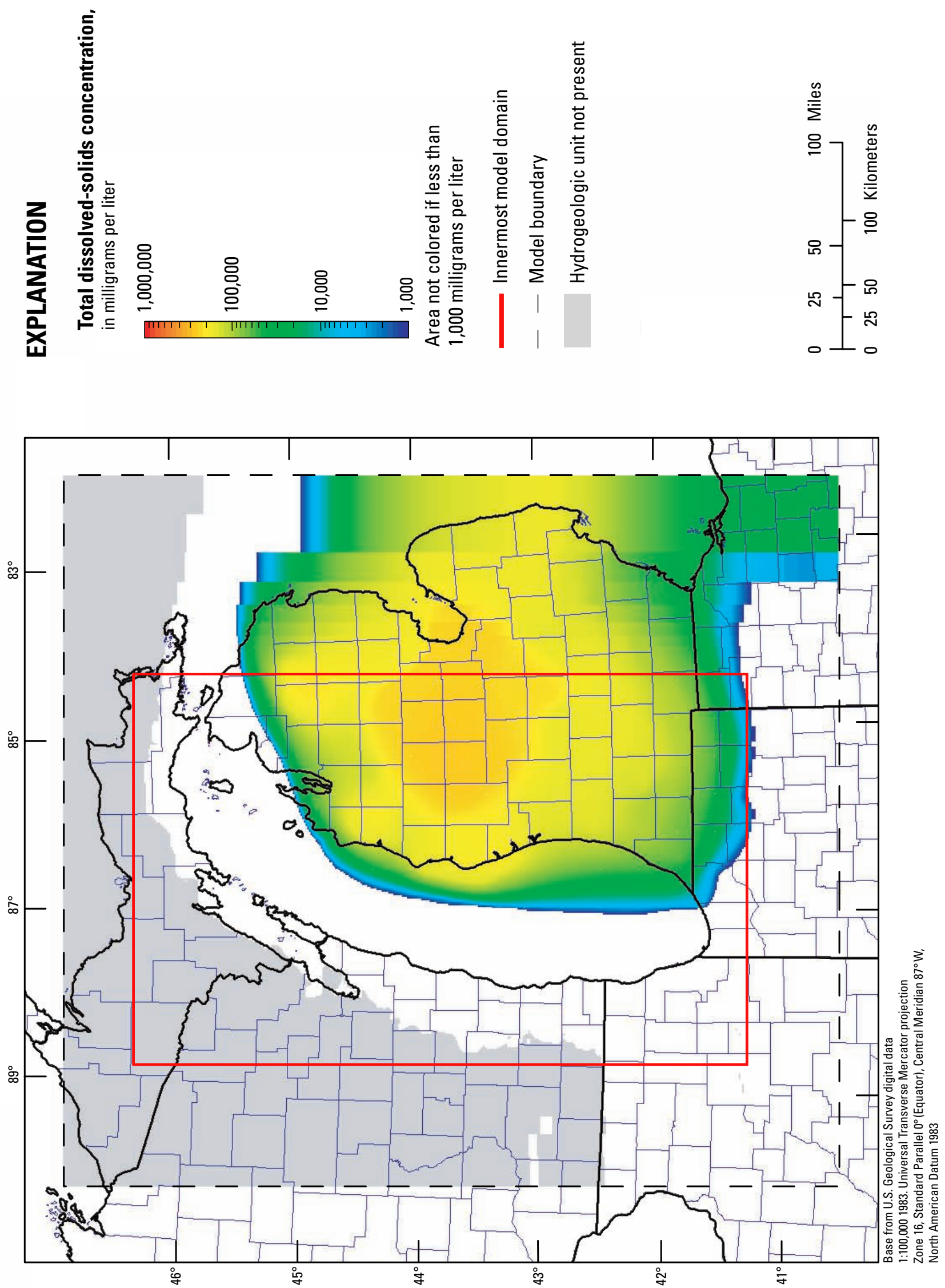

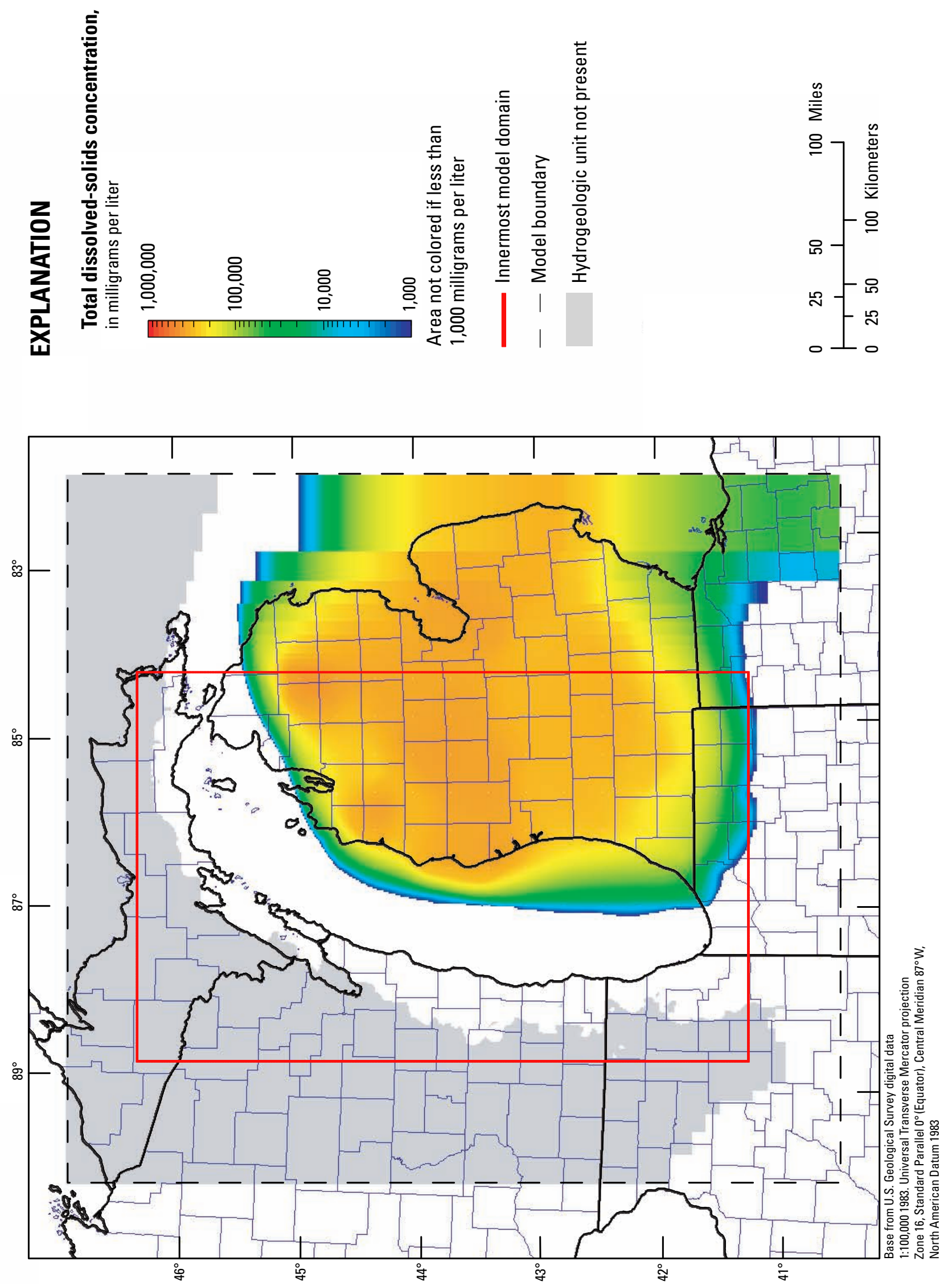

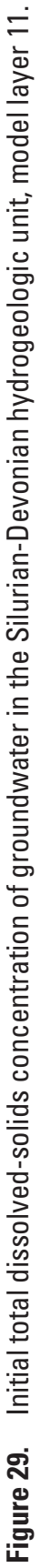





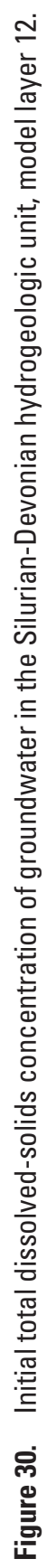




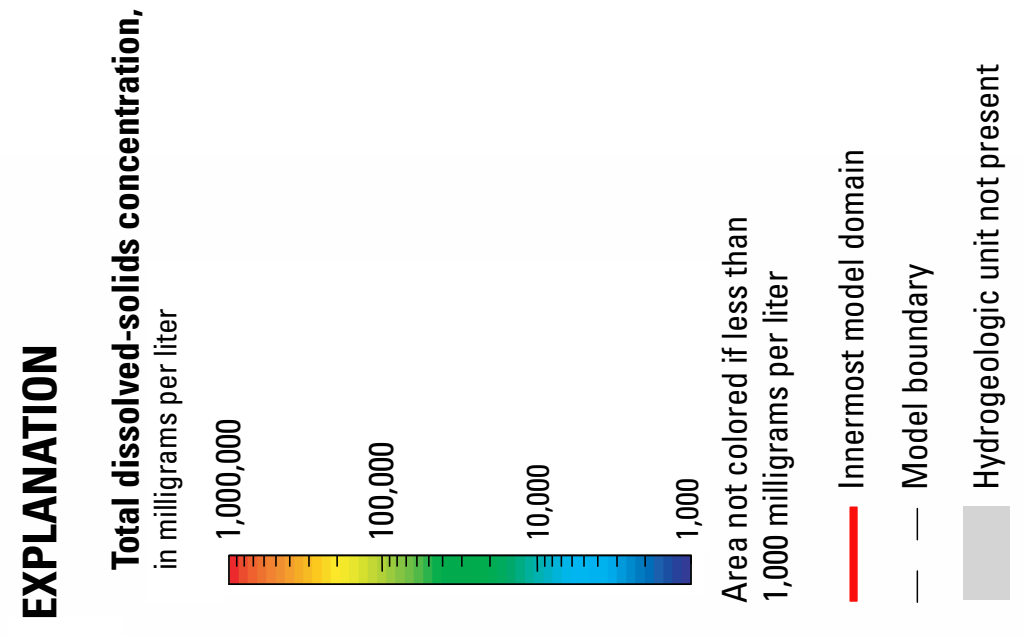



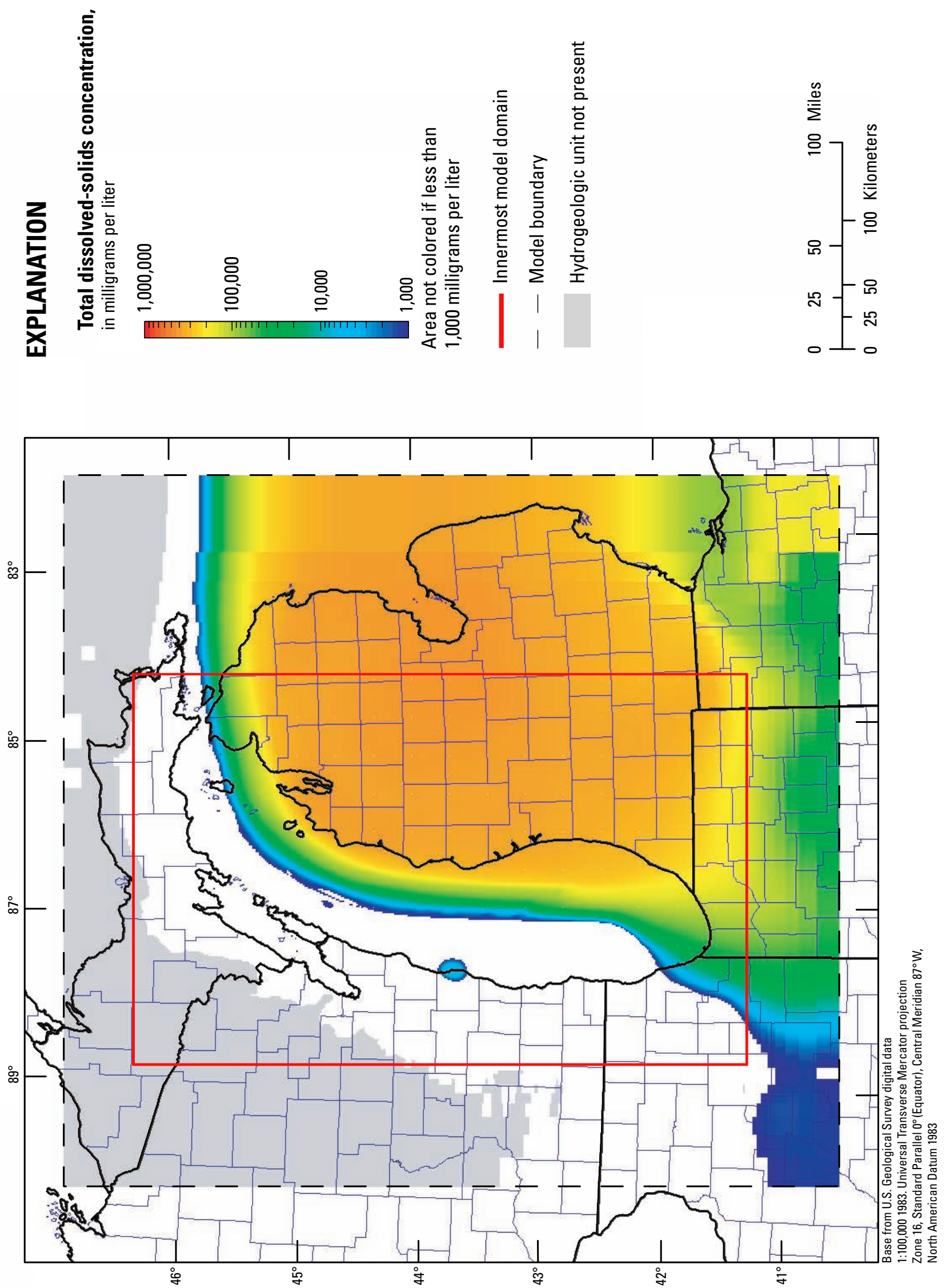

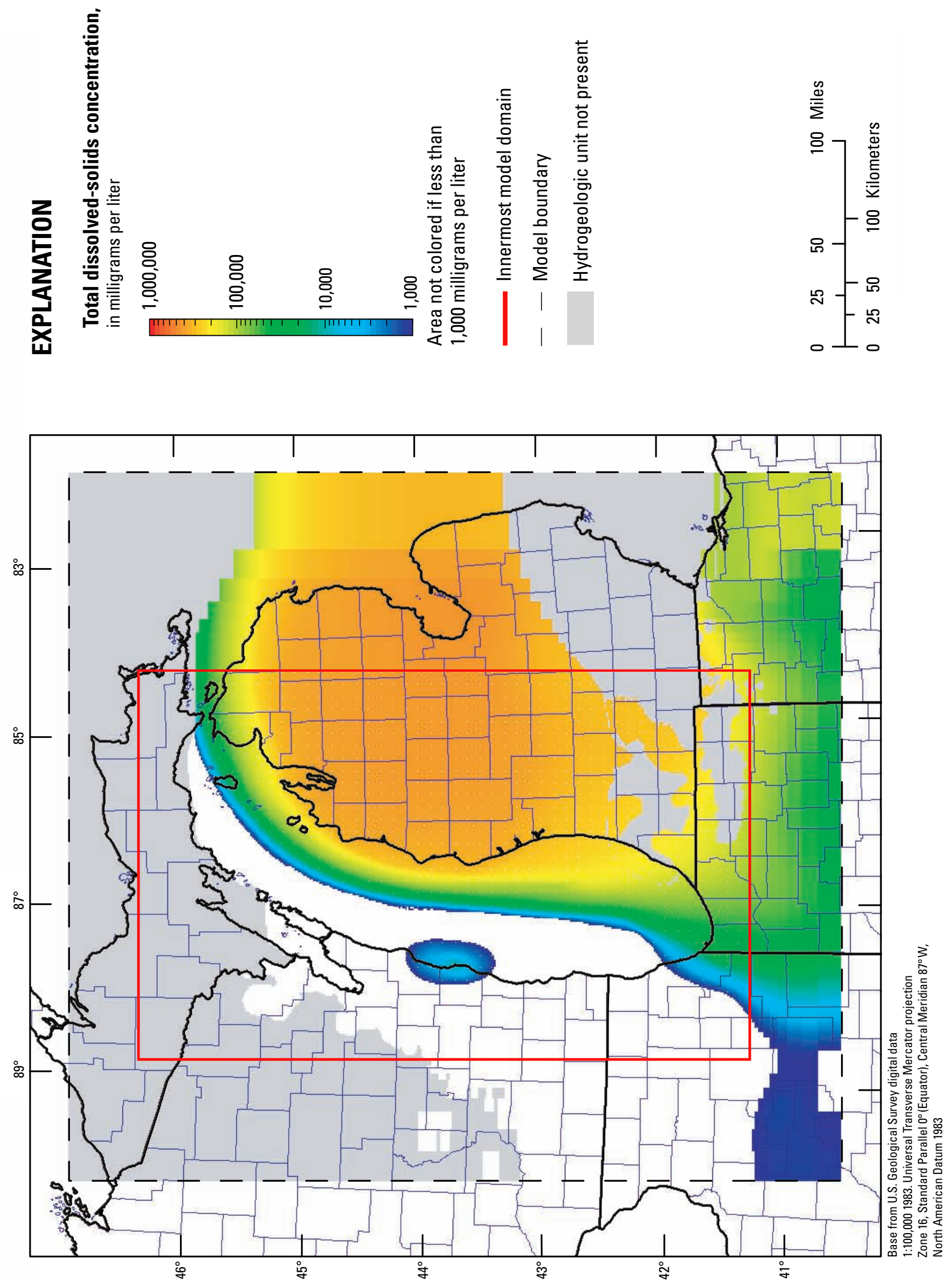

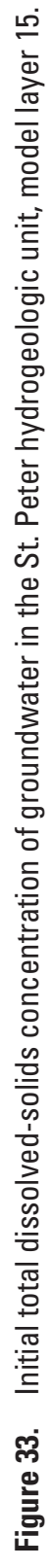



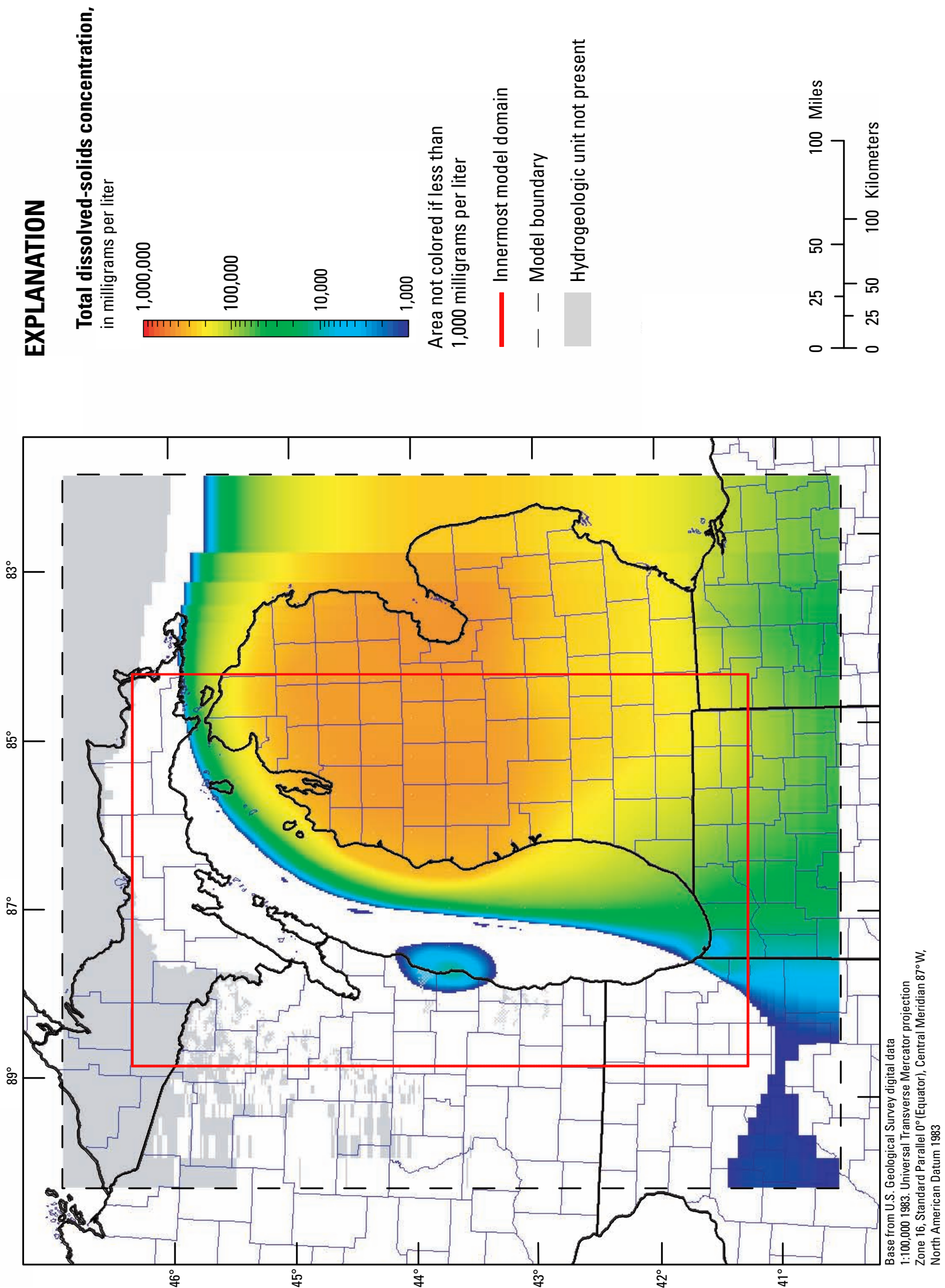

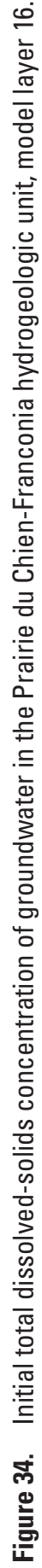



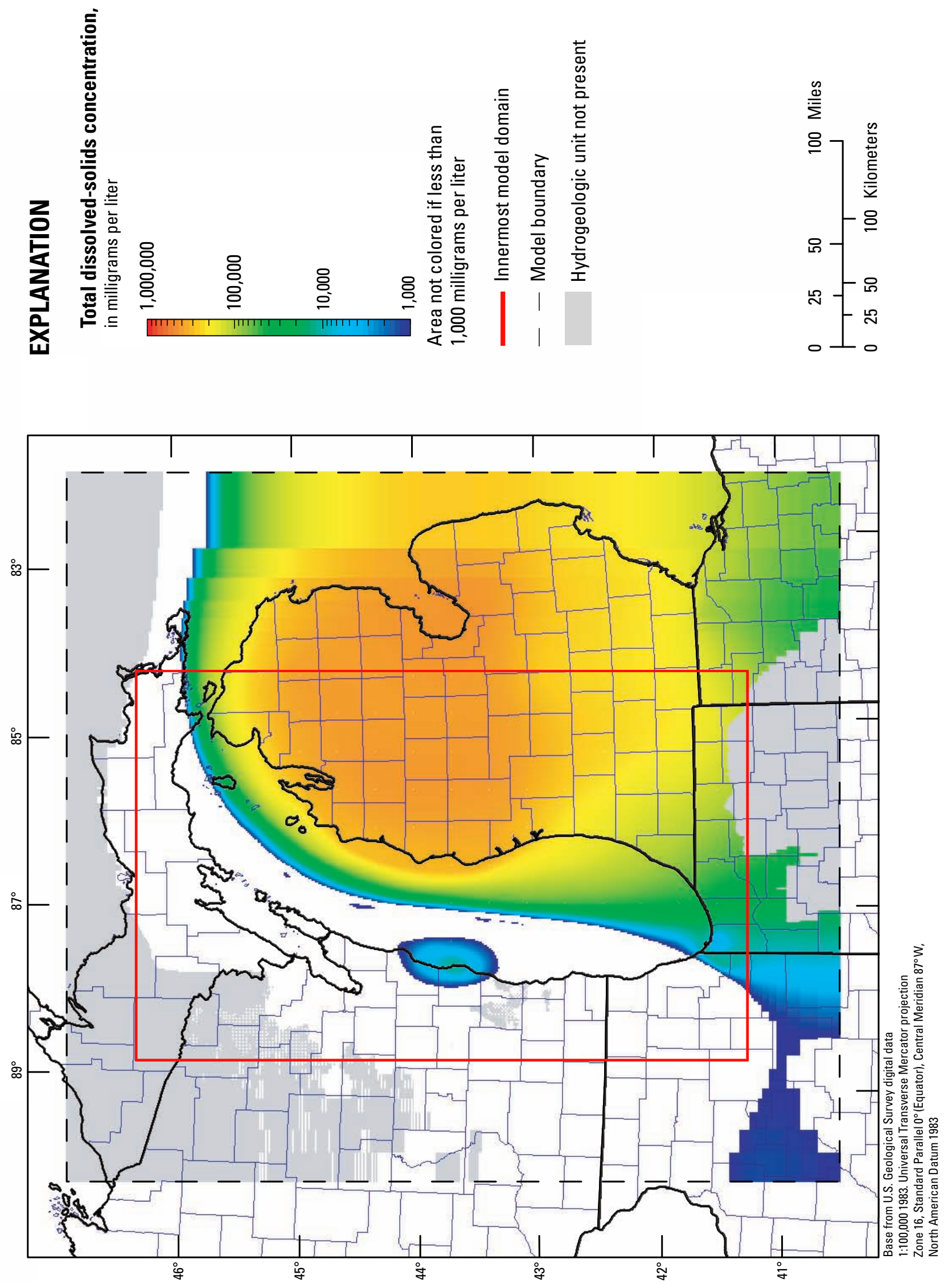

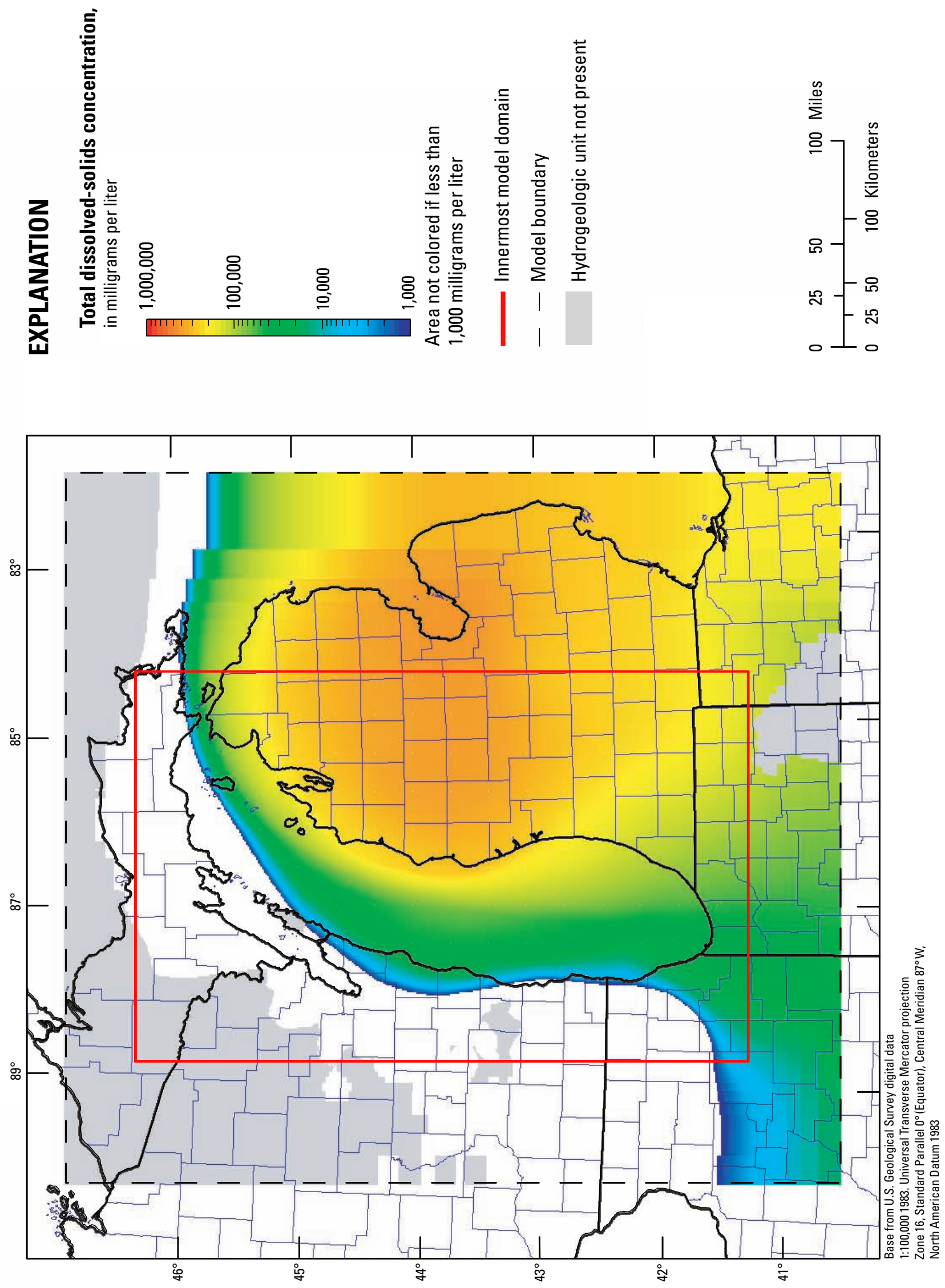





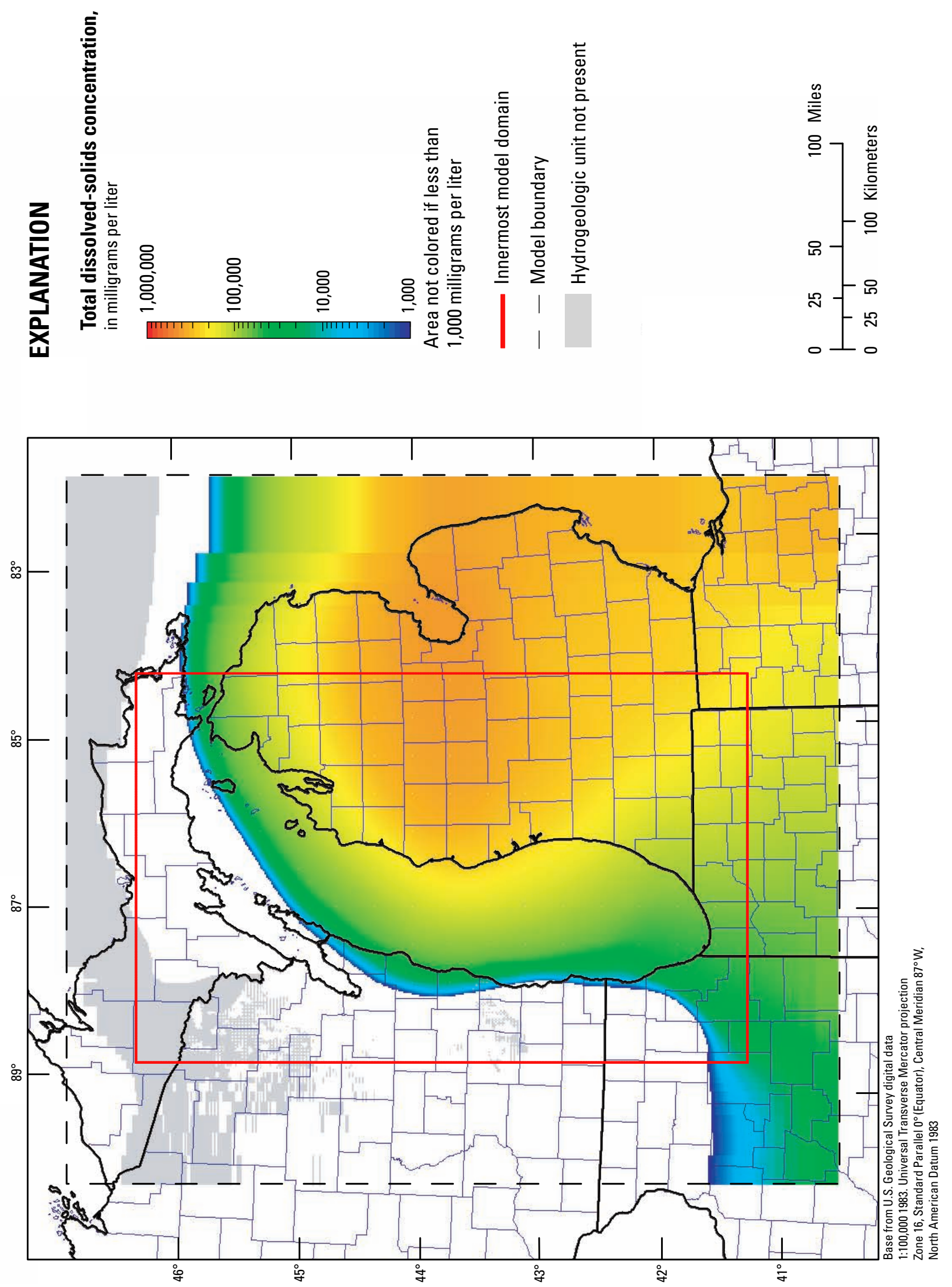

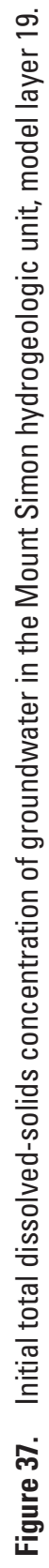



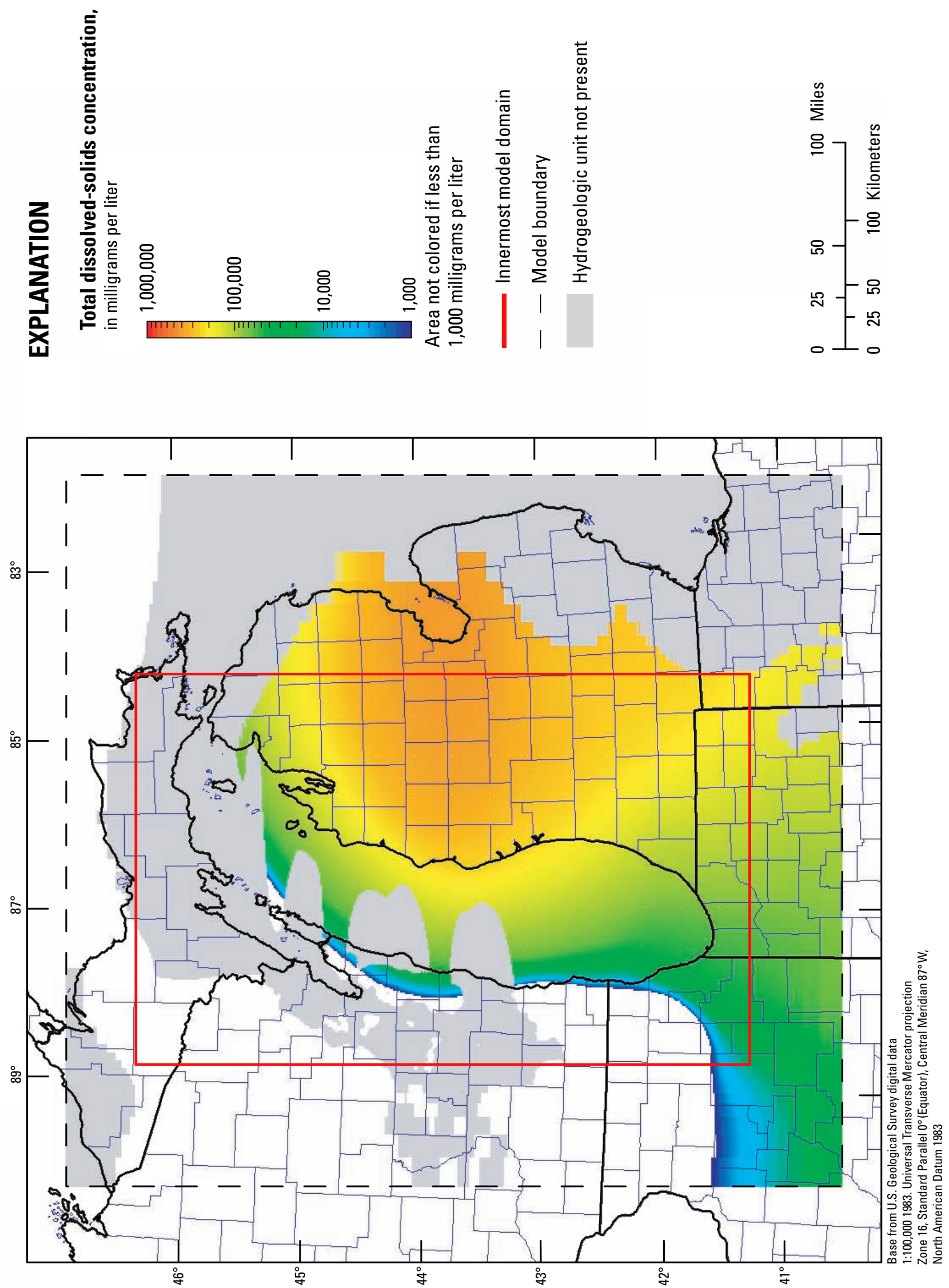

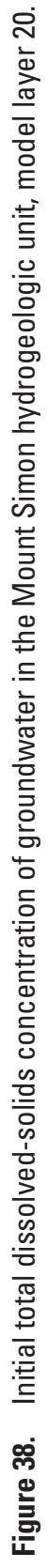


Table 4. Hydrogeologic units, model layers, data sources, and maximum total dissolved-solids concentration for the initial salinity concentrations.

[Data presented in this report are referred to as salinity data and are reported in terms of total dissolved solids (TDS)]

\begin{tabular}{|c|c|c|c|}
\hline Hydrogeologic unit & Model layer & Sources of data & $\begin{array}{l}\text { Maximum total } \\
\text { dissolved-solids } \\
\text { concentration } \\
\text { (milligrams per liter) }\end{array}$ \\
\hline \multirow{3}{*}{ Quaternary } & 1 & Data available & 6,549 \\
\hline & 2 & Assigned from model layer 1 & 2,861 \\
\hline & 3 & Assigned from model layer 1 & 1,067 \\
\hline Jurassic & 4 & Interpolated from model layers 1 and 5 & 2,049 \\
\hline Upper Pennsylvanian & 5 & Data available & 5,034 \\
\hline Lower Pennsylvanian & 6 & Assigned from model layer 5 & 5,034 \\
\hline Michigan & 7 & Interpolated from model layers 5 and 8 & 66,658 \\
\hline Marshall & 8 & Data available & 131,950 \\
\hline Devonian-Mississippian & 9 & Interpolated from model layers 8 and 11 & 249,075 \\
\hline \multirow{3}{*}{ Silurian-Devonian } & 10 & Interpolated from model layers 8 and 11 & 249,075 \\
\hline & 11 & Data available & 401,799 \\
\hline & 12 & Assigned from model layer 11 & 401,799 \\
\hline Maquoketa & 13 & Interpolated from model layers 11 and 14 & 379,760 \\
\hline Sinnipee & 14 & Data available & 402,589 \\
\hline St. Peter & 15 & Interpolated from model layers 14 and 16 & 407,106 \\
\hline Prairie du Chien-Franconia & 16 & Data available & 413,623 \\
\hline Ironton-Galesville & 17 & Assigned from model layer 16 & 413,623 \\
\hline Eau Claire & 18 & Interpolated from model layers 17 and 19 & 399,180 \\
\hline \multirow{2}{*}{ Mount Simon } & 19 & Data available & 386,410 \\
\hline & 20 & Data available & 386,410 \\
\hline
\end{tabular}

\section{Summary}

The U.S. Geological Survey is assessing the availability and use of our Nation's water resources to gain a clearer understanding of the status those resources. A hydrogeologic framework and distribution of total dissolved-solids concentrations were developed for input into a groundwater-flow model of the Lake Michigan Basin and surrounding area. The geology of the study area was divided into 15 hydrogeologic units that describe the glacial and bedrock geology of the study area. Five of the 15 hydrogeologic units simulate aquifer materials, 4 of the 15 units simulate confining unit materials, and 6 of the 15 units describe units that have properties of aquifers and confining units. These hydrogeologic units were subdivided into 20 layers to be used within the Lake Michigan Basin groundwater-flow model. The Jurassic, Lower Pennsylvanian, Marshall and Ironton-Galesville hydrogeologic units have thicknesses less than $550 \mathrm{ft}$. The Silurian-Devonian hydrogeologic unit has thicknesses less than about 7,550 ft.

A related background investigation identified different data sources that could be used to characterize the groundwater resources of the study area. Existing models, well log databases, and geologic maps provided data to define the extent and depth of each hydrogeologic unit within the study area. Well log databases were assigned to multiple hydrogeologic units based on the lithologic log associated with each well. Data for each hydrogeologic unit were grouped and converted into a GIS based database. The hydrologic frameworks for 
existing models were converted to nodal data points, assigned to a hydrogeologic unit, and converted into a GIS database. Isopach and structural contour maps were digitized, and elevation surfaces for each hydrogeologic unit were generated by use of a GIS. The interpolated surfaces of each hydrogeologic unit were then converted into point GIS databases. These data were merged, interpolated by use of a GIS, and then converted to ASCII format text files that could be imported into the groundwater-flow model.

Data were also compiled to define an initial distribution of total dissolved-solids concentrations that would be used to simulate the effects of density-driven flow of groundwater within the study area. Data presented in this report are referred to as "salinity data" and are reported in terms of total dissolved solids. When datasets were reported only in terms of density, total dissolved solids concentrations were derived by use of a linear regression developed from datasets that report both total dissolved solids concentration and density. Individual data points and contours of total dissolved-solids concentration and density for hydrologic units were combined and interpolated by use of a kriging interpolator for model layers with available data. Those layers without data were assigned values based on available data from layers above and below. The interpolated distributions for each model layer were then converted to ASCII format text files that could be imported into the groundwater-flow model. Model layers in the Quaternary, Jurassic, Upper Pennsylvanian, Lower Pennsylvanian, and Michigan hydrogeologic units have total dissolved-solids concentrations less than 100,000 mg/L. Model layers in the Silurian-Devonian, Sinnipee, St. Peter, Prairie du Chien-Franconia, and Ironton-Galesville hydrogeologic units have total dissolved-solids concentrations greater than $400,000 \mathrm{mg} / \mathrm{L}$.

\section{Acknowledgments}

Thanks are extended to the Illinois State Water Survey, Wisconsin Geological and Natural History Survey, Ohio Division of Geological Survey, and the Indiana Geological Survey for providing expertise and data used for this project. Neeraj Gupta is thanked for providing an extensive salinity dataset for the Midwest. Daniel Feinstein and Cheryl Buchwald of the U.S. Geological Survey provided valued assistance by compiling the sources for bedrock lithologies for Wisconsin. Howard Reeves and Chris Hoard of the U.S. Geological Survey provided valued assistance by compiling sources for bedrock lithology and salinity within Michigan.

\section{References Cited}

Arihood, L.D., 2008, Processing, analysis, and general evaluation of well-driller records for estimating hydrogeologic parameters of the glacial sediments in a ground-water flow model of the Lake Michigan Basin: U.S. Geological Survey Scientific Investigations Report 2008-5184, 26 p.

Batten, W.G., 2004, Preliminary Paleozoic geologic map of Fond du Lac County, Wisconsin: Wisconsin Geological and Natural History Survey Open-File Report 2004-23, scale $1: 100,000,1 \mathrm{pl}$.

Batten, W.G., 1987, Water resources of Langlade County, Wisconsin: Wisconsin Geological and Natural History Survey Information Circular 58, $28 \mathrm{p}$.

Bond, D.C., 1972, Hydrodynamics in deep aquifers of the Illinois basin: Illinois State Geological Survey Circular 470, $72 \mathrm{p}$.

Bricker, D.M., Milstein, R.L., and Reszka, C.R., Jr., 1983, Selected studies of Cambro-Ordovician sediments within the Michigan Basin: Michigan Geological Survey Report of Investigation 26, 54 p.

Buschbach, T.C., 1964, Cambrian and Ordovician strata of northeastern Illinois: Illinois State Geological Survey Report of Investigation 218, 90 p.

Catacosinos, P.A., Westjohn, D.B., Harrison III, W.B., Wollensak, M.S., and Reynolds, R.F., 2001, Stratigraphic lexicon for Michigan: Michigan Department of Environmental Quality, Geological Survey Division Bulletin 8, 56 p.

Cohee, G.V., Macha, C., and Holk, M., 1951, Thickness and lithology of upper Devonian and Carboniferous rocks in Michigan: U.S. Geological Survey Oil and Gas Investigation Chart 41, 5 sheets.

Colton, G.W., 1962, Geologic summary of the Appalachian Basin, with reference to the subsurface disposal of radioactive waste solutions: U.S. Geological Survey Open-File Report 62-28, $121 \mathrm{p}$.

Eaton, T.T., Bradbury, K.R., and Evans, T.J., 1999, Characterization of the hydrostratigraphy of the deep sandstone aquifer in southeastern Wisconsin: Wisconsin Geological and Natural History Survey Open-File Report 1999-02, 30 p.

Eberts, S.M., and George, L.L., 2000, Regional ground-water flow and geochemistry in the Midwest Basins and Arches aquifer system in parts of Indiana, Ohio, Michigan and Illinois: U.S. Geological Survey Professional Paper 1423-C, $103 \mathrm{p}$. 
Environmental Systems Research Institute, 2003, ARC-INFO, version 8.3: Redlands, Calif.

Feinstein, D.T., Eaton, T.T., Hart, D.J., Krohelski, J.T., and Bradbury, K.R., 2005, A regional aquifer simulation model for southeastern Wisconsin, Report 1-Data collection, conceptual model development, numerical model construction, and model calibration: Southeastern Wisconsin Regional Planning Commission, Technical Report 41, 81 p.

Ging, P.B., Long, D.T., and Lee, R.W., 1996, Selected geochemical characteristics of ground water from the Marshall aquifer in the central Lower Peninsula of Michigan: U.S. Geological Survey Water-Resources Investigations Report 94-4220, $19 \mathrm{p}$.

Golden Software Inc., 2002, Surfer, version 8.00: Golden, Colo.

Grannemann, N.G., and Reeves, H.W., 2005, Great Lakes Basin water availability and use-A study of the National Assessment of Water Availability and Use Program: U.S. Geological Survey Fact Sheet 2005-3113, 4 p.

Gray, H.H., 2003, Bedrock topography contours, Indiana: Indiana Geological Survey, 1:500,000, Line Shapefile. Accessed April 4, 2008, at URL http://igs.indiana.edu/ arcims/statewidel download.html.

Gray, H.H., Droste, J.B., Patton, J.B., Rexroad, C.B., Shaver, R.H., 1985, Correlation chart showing Paleozoic supplement stratigraphic units of Indiana: Indiana Geological Survey Miscellaneous Map 48.

Gupta, Neeraj, 1993, Geologic and fluid-density controls on the hydrodynamics of the Mt. Simon Sandstone and overlying geologic units in Ohio and Surrounding states: Columbus, Ohio, The Ohio State University, Ph.D. dissertation, $266 \mathrm{p}$.

Harbaugh, A.W., Banta, E.R., Hill, M.C., and McDonald, M.G., 2000, MODFLOW-2000, The U.S. Geological Survey modular ground-water model - User guide to modularization concepts and the ground-water flow process: U.S. Geological Survey Open-File Report 00-92, 121 p.

Hem, J.D., 1985, Study and interpretation of the chemical characteristics of natural water ( $3 \mathrm{~d}$ ed.): U.S. Geological Survey Water-Supply Paper 2254, 264 p.

Hull, D.N., 1990 (compiler), revised by Larson, G.E., 2000, and Slucher, E.R., 2004, Generalized column of bedrock units in Ohio: Ohio Department of Natural Resources, Division of Geological Survey, accessed April 24, 2008, at URL http://www.dnr.state.oh.us/Portals/10/pdf/stratcol.pdf.

Indiana Geological Survey, 2005, Petroleum Database Management System: Microsoft SQL Server database for managing petroleum well data in Indiana. Accessed December 18, 2008, at URL http://igs.indiana.edu/pdms/.
Kammerer, P.A., 1998, Geology, ground-water flow, and dissolved-solids concentrations in ground water along hydrogeologic sections through Wisconsin aquifers: U.S. Geological Survey Hydrologic Atlas 731, 4 sheets.

Kolata, D.R., 1990, Overview of sequences. in Leighton, M.W., Kolata, D.R., Oltz, D.F., and Eidel, J.J., eds., Interior cratonic basins: Tulsa, Okla., American Association of Petroleum Geologists Memoir 51, p. 59-73.

Kolata, D.R., and Graese, A.M., 1983, Lithostratigraphy and depositional environments of the Maquoketa Group (Ordovician) in northern Illinois: Illinois State Geological Survey Circular 528, $49 \mathrm{p}$.

Kontis, R.J., and Mandle, A.L., 1980, Data-base system for northern Midwest regional aquifer-system analysis: U.S. Geological Survey Water-Resources Investigations Report 80-104, 23 p.

Krohelski, J.T., Bradbury, K.R., Hunt, R.J., and Swanson, S.K., 2000, Numerical simulation of groundwater flow in Dane County, Wisconsin: Wisconsin Geological and Natural History Survey Bulletin 98, $31 \mathrm{p}$.

Langevin, C.D., Shoemaker, W.B., and Guo, Weixing, 2003, MODFLOW-2000, the U.S. Geological Survey modular ground-water model —Documentation of the SEAWAT-2000 version with the variable-density flow process (VDF) and the Integrated MT3DMS transport process (IMT): U.S. Geological Survey Open-File Report 03-426, 43 p.

Lloyd, O.B., and Lyke, W.L., 1995, Ground-water atlas of the United States-Segment 10, Illinois, Indiana, Kentucky, Ohio, and Tennessee: U.S. Geological Survey Hydrologic Atlas $730-\mathrm{K}, 30 \mathrm{p}$.

Meissner, B.D., Long, D.T., and Lee, R.W., 1996, Selected geochemical characteristics of ground water from the Saginaw aquifer in the central Lower Peninsula of Michigan: U.S. Geological Survey Water-Resources Investigations Report 93-4220, $19 \mathrm{p}$.

Michigan Department of Environmental Quality, 1987, Bedrock geology, polygon Shapefile, scale 1:63,360. Accessed December 18, 2008, at http://www.mcgi.state. mi.us $/ \mathrm{mgdl} /$ ? rel=thext\&action $=$ thmname $\&$ cid $=2 \&$ cat $=$ Bedrock+Geology.

Michigan Department of Environmental Quality, 2008, Wellogic, Statewide Ground Water Database (SGWD): Michigan Department of Environmental Quality (continuously updated). Accessed March 28, 2008, at URL http:// www.mcgi.state.mi.us $/ \mathrm{mgdl}$ ? rel=thext\&action=thmname \& cid $=2 \&$ cat $=$ Drinking + Water + Wells. 
Mikulic, D.R., Sargent, M.L., Norby, R.D., and Kolata, D.R., 1985, Silurian geology of the Des Plaines River valley, northeastern Illinois: Illinois State Geological Survey Guidebook 17, 56 p.

Nadon, G.C., Simo, J.A., Dott, R.H., Jr., and Byers, C.W., 2000, High-resolution sequence stratigraphic analysis of the St. Peter Sandstone and Glenwood Formation (Middle Ordovician), Michigan Basin, U.S.A.: American Association of Petroleum Geologists Bulletin, v. 84, p. 975-996.

Nicholas, J.R., Sherrill, M.G., and Young, H.L., 1987, Hydrogeology of the Cambrian-Ordovician aquifer system at a test well in northeastern Illinois: U.S. Geological Survey Water-Resources Investigations Report 84-4165, 30 p.

Ohio Division of Geological Survey, 2005, Bedrock topography of Ohio: Ohio Division of Geological Survey CD-ROM BG-3.

Olcott, P.C., 1966, Geology and water resources of Winnebago County, Wisconsin: U.S. Geological Survey Water-Supply Paper 1814, 61 p.

Olcott, P.C., 1992, Ground-water atlas of the United StatesSegment 9, Iowa, Michigan, Minnesota, and Wisconsin: U.S. Geological Survey Hydrologic Atlas 730-J, 31 p.

Reed, J.C., Jr., and Bush, C.A., 2005, Generalized geologic map of the United States, Puerto Rico, and the U.S. Virgin Islands, version 2.0: U.S. Geological Survey digital data, Accessed January 24, 2008, at URL http://pubs.usgs.gov/ atlas/geologic/.

Ryling, R.W., 1961, A preliminary study of the distribution of saline water in the bedrock aquifers of eastern Wisconsin: Wisconsin Geological and Natural History Survey Information Circular number 5, $23 \mathrm{p}$.

Schnoebelen, D.J., Bugliosi, E.F., Hanover, R.H., and Rupp, J.A., 1998, Approximate location of the 10,000-milligram-per-liter dissolved-solids boundary in the Silurian and Devonian carbonate-rock aquifer, southwestern and northern Indiana: U.S. Geological Survey Water-Resources Investigations Report 95-4071, 12 p.

Schnoebelen, D.J., Bugliosi, E.F., and Krothe, N.C., 1995, Delineation of a saline ground-water boundary from borehole geophysical data: Ground Water, v. 33, no. 6, p. $965-976$.

U.S. Geological Survey, 2002, Concepts for national assessment of water availability and use: U.S. Geological Survey Circular 1223, $34 \mathrm{p}$.

Visocky, A.P., Sherrill, M.G., and Cartwright, Keros, 1985, Geology, hydrology, and water quality of the Cambrian and Ordovician Systems in northern Illinois: Illinois State Geological Survey Cooperative Groundwater Report 10, 136 p.
Wahrer, M.A., Long, D.T., and Lee, R.W., 1996, Selected geochemical characteristics of ground water from the glaciofluvial aquifer in the central Lower Peninsula of Michigan: U.S. Geological Survey Water-Resources Investigations Report 94-4017, $21 \mathrm{p}$.

Wickstrom, L.H., Gray, J.D., and Stieglitz, R.D., 1992, Stratigraphy, structure, and production history of the Trenton Limestone (Ordovician) and adjacent strata in northwestern Ohio: Ohio Division of Geological Survey Report of Investigations 143,78 p., 1 pl.

Willman, H.B., Atherton, E., Buschbach, T.C., Collinson, C., Frye, J.C., Hopkins, M.E., Lineback, J.A., and Simon, J.A., 1975, Handbook of Illinois stratigraphy: Illinois State Geological Survey Bulletin 95, 261 p.

Wisconsin Department of Natural Resources, 2006, Water well data-Wisconsin well construction reports plus other related files: Wisconsin Bureau of Drinking Water and Groundwater, created December 6, 2005, CD-ROM.

Wisconsin Geological and Natural History Survey, 2004, wiscLITH: A digital lithologic and stratigraphic database of Wisconsin geology: Wisconsin Geological and Natural History Survey Open-File Report 2003-05, 39 p.

Wisconsin Geological and Natural History Survey, 2006, Bedrock stratigraphic units in Wisconsin: Wisconsin Geological and Natural History Survey Open-File Report 2006-06, 1 p.

Young, H.L., 1992, Summary of ground-water hydrology of the Cambrian-Ordovician aquifer system in the northern Midwest, United States: U.S. Geological Survey Professional Paper 1405-A, 55 p.

Young, H.L. and Siegel, D.I., 1992. Hydrogeology of the Cambrian-Ordovician aquifer system in the northern Midwest, United States: U.S. Geological Survey Professional Paper 1405-B, 99 p. 
e

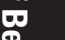

응

芦

急

$\frac{2}{40}$

兰

둥

.

홀

क.

蛋 